University of Nebraska - Lincoln

DigitalCommons@University of Nebraska - Lincoln

Zebra Chip Disease of Potato: Biology, Epidemiology, and

Management

Joseph E. Munyaneza

USDA-ARS, joseph.munyaneza@ars.usda.gov

Follow this and additional works at: https://digitalcommons.unl.edu/usdaarsfacpub

Munyaneza, Joseph E., "Zebra Chip Disease of Potato: Biology, Epidemiology, and Management" (2012). Publications from USDA-ARS / UNL Faculty. 1275.

https://digitalcommons.unl.edu/usdaarsfacpub/1275

This Article is brought to you for free and open access by the U.S. Department of Agriculture: Agricultural Research Service, Lincoln, Nebraska at DigitalCommons@University of Nebraska - Lincoln. It has been accepted for inclusion in Publications from USDA-ARS / UNL Faculty by an authorized administrator of DigitalCommons@University of Nebraska - Lincoln. 


\title{
Zebra Chip Disease of Potato: Biology, Epidemiology, and Management
}

\author{
Joseph E. Munyaneza
}

Published online: 30 August 2012

(C) Potato Association of America 2012

This article is a U.S. government work, and is not subject to copyright in the United States.

\begin{abstract}
Zebra chip (ZC), a new and economically important disease of potato (Solanum tuberosum L.), has been documented to occur in commercial potato fields in the United States, Mexico, Central America, and New Zealand. This disease has caused millions of dollars in losses to the potato industry. Whole crops might be rejected because of $\mathrm{ZC}$, often leading to abandonment of entire fields. Plant growth and yield are severely affected by the disease. Additionally, chips or fries processed from ZC-infected tubers exhibit dark stripes that become markedly more visible with frying, and hence are commercially unacceptable. The disease causes serious losses to the fresh market, tablestock and export potato industry as well. ZC-infected tubers usually do not sprout and if they do, produce hair sprouts or weak plants. Finally, there are indications that ZC symptoms might develop in tubers during storage. $\mathrm{ZC}$ has been associated with a previously undescribed species of liberibacter, tentatively named "Candidatus Liberibacter solanacearum", also known as " $\mathrm{Ca}$. L. psyllaurous". The bacterium is transmitted to potato by the potato psyllid, Bactericera cockerelli (Šulc). All commercial potato cultivars appear to be susceptible to ZC, and management tactics targeted against the potato psyllid are currently the only means to effectively manage the disease. Furthermore, there are concerns about quarantine and trade issues in psyllid-affected regions because some countries may require that shipments of potatoes from certain growing regions be tested for the disease before the shipments are allowed entry. ZC history, geographic distribution, biology, epidemiology, and management are discussed herein.
\end{abstract}

\footnotetext{
J. E. Munyaneza $(\bowtie)$

United States Department of Agriculture-Agricultural Research

Service, Yakima Agricultural Research Laboratory,

5230 Konnowac Pass Road,

Wapato, WA 98951, USA

e-mail: joseph.munyaneza@ars.usda.gov
}

Resumen Se ha documentado que Zebra chip (ZC), una enfermedad nueva y económicamente importante de la papa (Solanum tuberosum L.), se presenta en los campos comerciales de papa en los Estados Unidos, México, América Central y Nueva Zelanda. Esta enfermedad ha causado millones de dólares en pérdidas a la industria de la papa. Se pudieran rechazar cultivos completos debido a ZC, que conducen a menudo al abandono total de los campos. Se afecta severamente el crecimiento y el rendimiento de la planta por la enfermedad. Además, las hojuelas o papas fritas procesadas de tubérculos infectados con ZC exhiben líneas oscuras que se vuelven marcadamente más visibles con el freído, y por lo tanto son inaceptables comercialmente. La enfermedad causa pérdidas serias al mercado fresco, al domestico y a la industria de la exportación también. Los tubérculos infectados con ZC generalmente no brotan, y si lo hacen, producen brotes ahilados y plantas débiles. Finalmente, hay indicaciones de que los síntomas de ZC pueden desarrollarse en los tubérculos durante el almacenamiento. Se ha asociado a la $\mathrm{ZC}$ con una especie previamente descrita de Liberibacter, tentativamente llamada "Candidatus Liberibacter solanacearum", también conocida como "Ca. L. psyllaurous". La bacteria se transmite a la papa por el psilido Bactericera cockerelli (Šulc). Todas las variedades comerciales de papa parecen ser susceptibles a ZC, y las tácticas de manejo dirigidas contra el psilido de la papa son a la fecha los únicos medios para manejar la enfermedad efectivamente. Aún mas, hay preocupación acerca de cuarentena y temas de comercio en regiones afectadas por el psilido, debido a que algunos países pudieran requerir que los embarques de papas de ciertas regiones de cultivo fueran analizados para la enfermedad antes de permitir la entrada de los envíos. De aquí que se discute la historia de ZC, la distribución geográfica, biología, epidemiología y el manejo. 
Keywords Potato psyllid - Bactericera cockerelli . Liberibacter $\cdot$ Potato $\cdot$ Zebra chip $\cdot$ Disease biology $\cdot$ Disease management

\section{Introduction}

Zebra chip (ZC), a new and economically important disease of potato (Solanum tuberosum L.), has so far been documented to occur in commercial potato fields in the United States, Mexico, Central America, and New Zealand (Secor and Rivera-Varas 2004; Munyaneza et al. 2007a; Liefting et al. 2008a; Secor et al. 2009; Crosslin et al. 2010; Espinoza 2010; Galviz et al. 2010; Munyaneza 2010; RubioCovarrubias et al. 2011a, b) (Fig. 1). ZC was first reported in 1994 in potatoes growing near Saltillo, Mexico (Secor and Rivera-Varas 2004; Munyaneza et al. 2007a, b; Crosslin et al. 2010; Secor et al. 2009). Initial records of the disease in the United States are from 2000 in potato fields in southern Texas (Munyaneza et al. 2007a, b; Secor et al. 2009). Infected fields of potatoes have since been documented in several other states, including Nebraska, Colorado, Kansas, Wyoming, New Mexico, Arizona, Nevada, and California (Munyaneza et al. 2007a, b; Secor et al. 2009; Crosslin et al. 2010; Munyaneza 2010), and most recently in Idaho, Oregon, and Washington (Hamm et al. 2011; Nolte et al. 2011; Crosslin et al. 2012a,b). In Central America, ZC has been reported from Guatemala and Honduras (Secor and Rivera-Varas 2004; Munyaneza et al. 2007a, b; Espinoza 2010; Rehman et al. 2010), and most recently from Nicaragua (Nicaragua-MAGFOR 2012). The disease is widespread in New Zealand (Teulon et al. 2009), where it was initially documented in 2008 (Liefting et al. 2008a). ZC is characterized by a severe dark and light striped symptom pattern in raw and fried chips and fries processed from infected tubers, affecting their taste and making them commercially unacceptable. Consumption of products processed from $\mathrm{ZC}$-infected tubers is not known to pose any human health issues.

ZC was of sporadic importance until 2004, when it began to cause millions of dollars in losses to potato growers in the Americas, often leading to the abandonment of entire fields (Secor and Rivera-Varas 2004; CNAS 2006; Gudmestad and

Fig. 1 Map (dark blue) showing geographic distribution of zebra chip disease in North and Central America

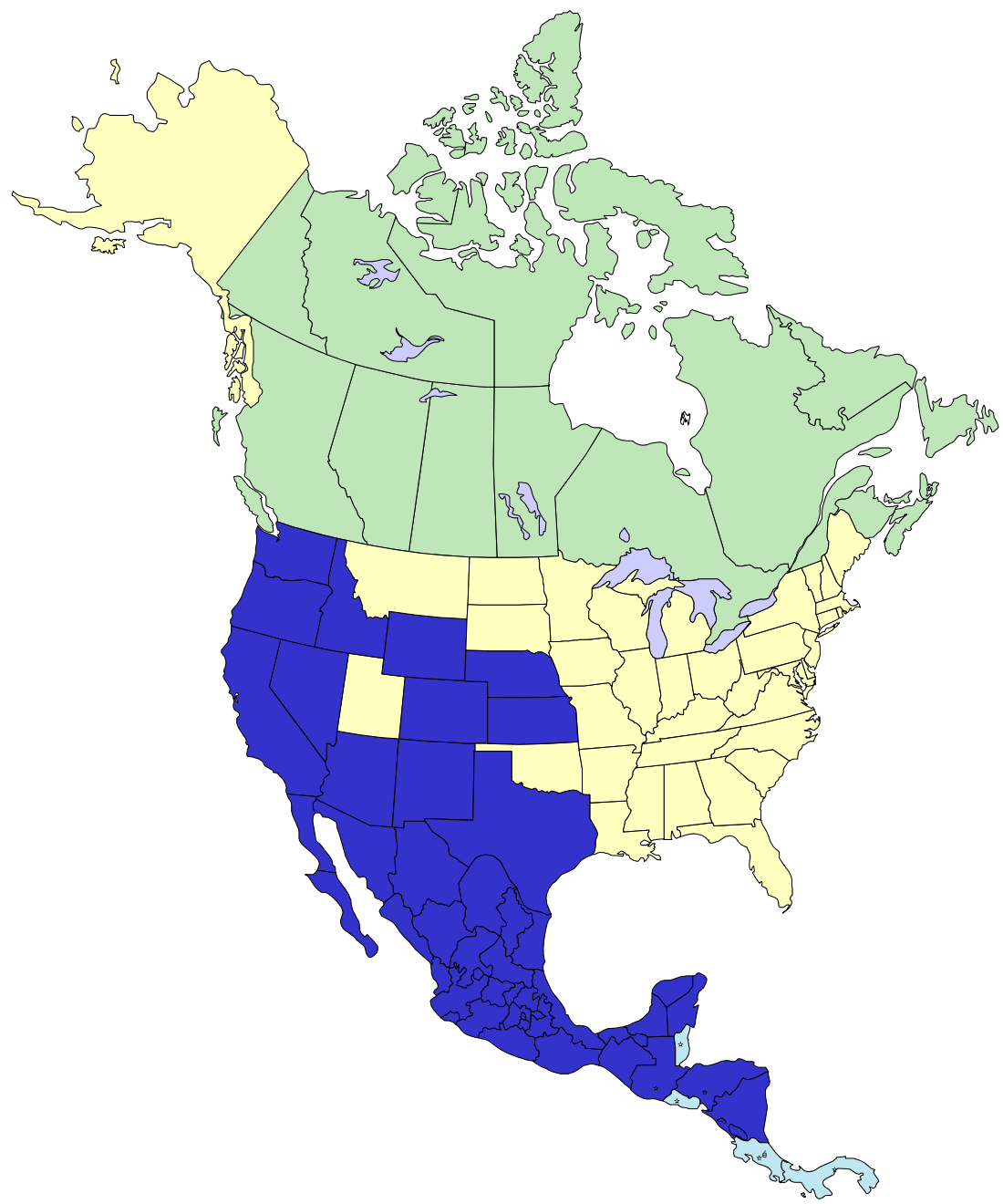


Secor 2007; Munyaneza et al. 2007a, b; 2009b; Crosslin et al. 2010; Galviz et al. 2010; Espinoza 2010; Munyaneza 2010; Rehman et al. 2010; Rubio-Covarrubias et al. 2011a, b). The disease has also devastated the potato industry in New Zealand (Liefting et al. 2008a; Teulon et al. 2009; Ogden 2011). ZC has been linked to a previously undescribed species of the bacterium liberibacter, tentatively named "Candidatus Liberibacter solanacearum", also known as "Ca. Liberibacter psyllaurous" (Hansen et al. 2008; Liefting et al. 2008a; 2009a,c). The bacterium is transmitted to potato by the potato/tomato psyllid, Bactericera cockerelli (Šulc) (Munyaneza et al. 2007a, b; Hansen et al. 2008; Secor et al. 2009; Buchman et al. 2011b; Butler and Trumble 2012a).

\section{Disease Description and Identification}

$\mathrm{ZC}$ is characterized by symptoms that develop in potato tubers, which consist of collapsed stolons, browning of vascular tissue, concomitant with necrotic flecking of internal tissues and streaking of the medullary ray tissues, all of which can affect the entire tuber (Fig. 2). Upon frying, these symptoms become more pronounced and chips or fries processed from infected tubers show very dark blotches, stripes, or streaks, rendering them commercially unacceptable (Munyaneza et al. 2007a,b; 2008; Secor et al. 2009; Crosslin et al. 2010; Miles et al. 2010; Buchman et al. 2011a,b; 2012) (Fig. 3). Foliar symptoms associated with ZC closely resemble those caused by psyllid yellows disease (Wallis 1955; Arslan et al. 1985; Sengoda et al. 2010) and purple top (Crosslin et al. 2005; Munyaneza et al. 2006; Ember et al. 2011), and include upward rolling of the top leaves developing into a basal cupping of the leaflets, accompanied with yellowish or purplish discoloration, proliferation of axillary buds, shortened internodes, swollen nodes, aerial tubers, leaf chlorosis and scorching, and rapid plant death (Munyaneza et al.2007a,b; Secor et al. 2009; Crosslin et al. 2010) (Fig. 4). The characteristic marking symptoms in potato tubers have led to the disease being named "zebra chip"
(Munyaneza et al. 2007a,b; Secor et al. 2009; Crosslin et al. 2010; Munyaneza 2010).

\section{Disease Causal Agent: "Candidatus Liberibacter solanacearum"}

The putative causal agent of ZC was unknown until 2008, when studies conducted in the United States and New Zealand showed that ZC is associated with a previously undescribed species of the bacterium liberibacter, tentatively named "Candidatus Liberibacter solanacearum" (referred to as 'Lso' hereafter), also known as " $\mathrm{Ca}$. Liberibacter psyllaurous" (Hansen et al. 2008; Liefting et al. 2008a; 2009a, c; Butler and Trumble 2012a). Subsequently, a series of studies confirmed presence of this bacterium in $\mathrm{ZC}$-infected potatoes from several geographic locations (Abad et al. 2009; Crosslin and Bester 2009; Crosslin and Munyaneza 2009; Lin et al. 2009; Munyaneza et al. 2009b; Secor et al. 2009; Sengoda et al. 2010; Crosslin et al. 2010; Rehman et al. 2010; Crosslin et al. 2012a,b). A comprehensive review of the history and association of this bacterium with $\mathrm{ZC}$ and other diseases of solanaceous crops was provided by Crosslin et al. (2010) and Munyaneza (2010). This bacterium is closely related to the liberibacters associated with Huanglongbing or citrus greening, the most destructive disease of citrus, which occurs in Asia, Africa, and the Americas (Bové 2006; Hansen et al. 2008; Liefting et al. 2009a, c; Lin et al. 2009; Wen et al. 2009; Lin et al. 2011a, b). The liberibacters are phloem-limited, Gram-negative, unculturable bacteria that belong to the Alphaproteobacteria group (Jagoueix et al. 1994; Bové 2006). These plant pathogens are spread from infected to healthy plants primarily by psyllid vectors (Bové 2006).

\section{Hosts and Geographic Distribution}

Lso has been reported from the western and central United States (Texas, Nebraska, Colorado, Kansas,
Fig. 2 Fresh potato tubers with zebra chip disease symptoms
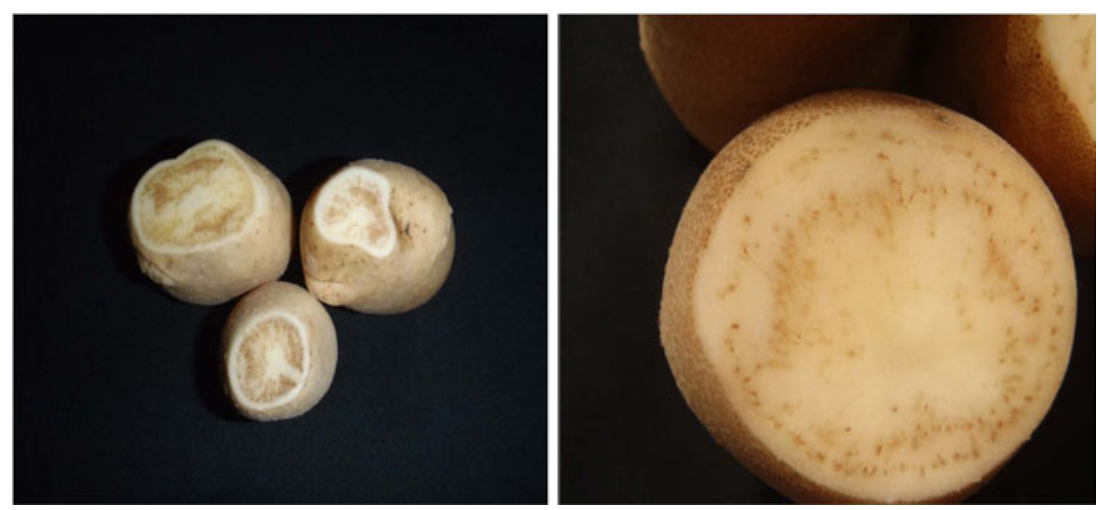
Fig. 3 Fried potato chips (a) and fries (b) processed from zebra chip disease-infected tubers
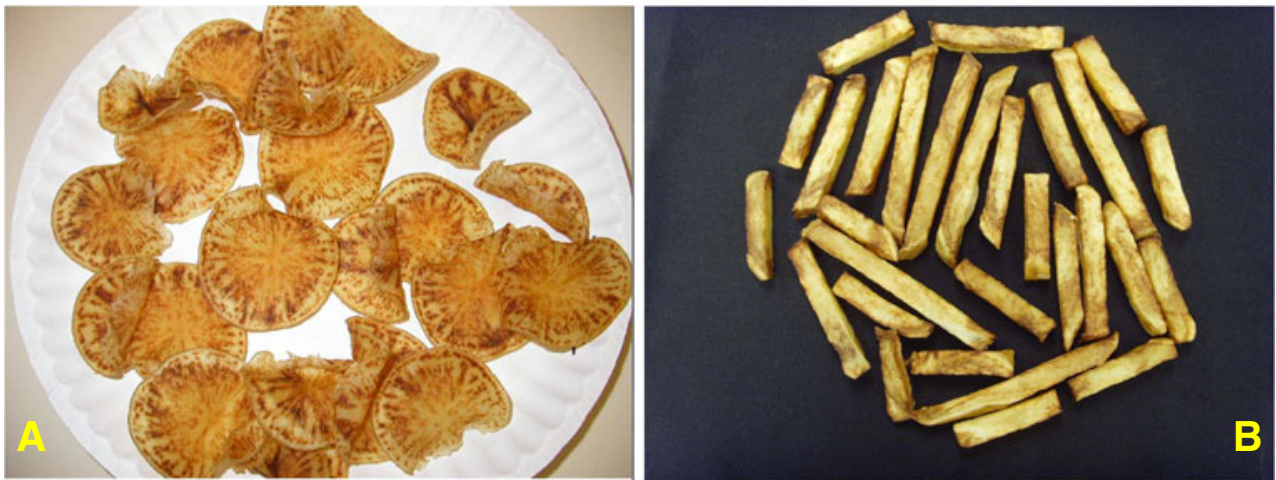

Wyoming, New Mexico, Arizona, Nevada, California, Idaho, Oregon, and Washington) (Hansen et al. 2008; Abad et al. 2009; Crosslin and Bester 2009; Crosslin and Munyaneza 2009; Lin et al. 2009; McKenzie and Shatters 2009; Secor et al. 2009; Brown et al. 2010; Crosslin et al. 2010; French-Monar et al. 2010; Munyaneza 2010; Crosslin et al. 2012a,b), Mexico (Munyaneza et al. 2009b,c,d), Central America (Guatemala, Honduras, and Nicaragua) (Rehman et al. 2010; NicaraguaMAGFOR 2012), and New Zealand (Liefting 2008a; 2009a,c). This species of liberibacter has also been documented on carrot (Daucus carota L.) in Northern Europe (Finland, Norway, and Sweden) (Munyaneza et al. 2010c,d; 2011c; 2012b,c) and the Mediterranean Region (Spain and the Canary Islands) (Alfaro-Fernández et al. 2012a,b). Furthermore, Lso has recently been reported on celery (Apium graveolens) crops in Spain (EPPO 2012).

Lso is known to primarily infect solanaceous crops, including potato, tomato (Solanum lycopersicon), pepper (Capsicum annuum), eggplant (Solanum melongena), tomatillo (Physalis spp.), tamarillo (Solanum betaceum), and several weeds in the family Solanaceae (Hansen et al. 2008; Liefting et al. 2008a,b; 2009a,c; Abad et al. 2009; Crosslin and Munyaneza 2009; Lin et al. 2009; Munyaneza et al. 2009b,c,d; Secor et al. 2009; Wen et al. 2009; Brown et al. 2010; Crosslin et al. 2010; Munyaneza 2010; Rehman et al. 2010; Sengoda et al. 2010). The pathogen is transmitted to solanaceous species by $B$. cockerelli. As noted above, Lso has very recently been detected for the first time in carrot plants in Finland, where it is vectored to carrot by the psyllid Trioza apicalis Förster (Munyaneza et al. 2010c, d; 2011c); this constitutes the first report of Lso in a non-solanaceous species. Subsequently, the bacterium was also detected in carrots and T. apicalis in Sweden and Norway (Munyaneza et al. 2012b, c). Most recently, Lso has been reported in carrot and celery crops and the psyllid Bactericera trigonica in the Canary Islands and mainland Spain (Alfaro-Fernández et al. 2012a, b; EPPO 2012). Damage to carrots by Lsoinfected psyllids in Europe can cause up to $100 \%$ crop loss (Munyaneza et al. 2010b, c; 2012b, c; Alfaro-Fernández et al. 2012a, b; Nissinen et al. 2012). In addition, there are reports of Lso having been detected in unidentified species of psyllids in the genera Acizzia and Trioza collected from Acacia and Pittosporum species, as well as foliage samples from these plant species in New Zealand (Scott et al. 2009). Furthermore, Lso was detected in one specimen of the psyllid Trioza chenopodii collected from Russia; however, further testing of other specimens failed to confirm presence of the bacterium (Kölber et al. 2010). These recent findings on the association of Lso with nonsolanaceous species suggest that this liberibacter species is likely to have more host plants and insect vectors than currently known.
Fig. 4 Potato plants infected with zebra chip disease and exhibiting symptoms of stunting, leaf chlorosis, yellowish and purplish discoloration, upward rolling of leaves, shortened internodes, and proliferation of axillary buds



\section{Biology}

Scanning electron microscopy images of Lso in sieves of infected plants showed that this bacterium has a rod-shaped morphology (Liefting et al. 2009a; Secor et al. 2009). The bacterium is about $0.2 \mu \mathrm{m}$ wide and $4 \mu \mathrm{m}$ long (Liefting et al. 2009a). Similarly to other liberibacters, Lso is spread from plants to plants by grafting (Crosslin and Munyaneza 2009; Secor et al. 2009) and psyllid vectors (Munyaneza et al. 2007a,b; Hansen et al. 2008; Secor et al. 2009; Munyaneza et al. 2010c,d: Buchman et al. 2011b; Alfaro-Fernández et al. 2012b). The pathogen has been shown to be transmitted to $B$. cockerelli both vertically (transovarially) and horizontally (from feeding on infected plant hosts) (Hansen et al. 2008; Munyaneza and Sengoda, unpublished data). Vertical transmission may contribute to the spread of ZC between geographic regions by dispersing psyllids, and also helps maintain the bacterium in geographic regions during the insect's overwintering period (Crosslin et al. 2010). No information is currently available on vertical transmission of Lso for T. apicalis and B. trigonica. It appears that Lso is not transmitted through true seed from infected solanaceous plants (Munyaneza, unpublished data; Liefting, personal communication).

Three geographic haplotypes of Lso have been described (Nelson et al. 2011). Two haplotypes (A and B) are associated with diseases caused by this bacterium in potatoes and other solanaceous plants, whereas the third (C) is associated with diseased carrots and the psyllid T. apicalis. The haplotypes were described by single nucleotide polymorphisms (SNPs) on the $16 \mathrm{~s}$ rRNA, $16 \mathrm{~s} / 23 \mathrm{~s}$ ISR and $50 \mathrm{~s}$ rplJ and rplL ribosomal protein genes (Nelson et al. 2011). These SNPs are inherited as a package across the three genes. Haplotype "A" has been found primarily from Honduras and Guatemala through western Mexico to Arizona and California, and in New Zealand. Haplotype "B" is currently known from eastern Mexico and northwards through Texas to south central Washington. These two haplotypes show some range overlap in Texas, Kansas and Nebraska. Haplotype "C" has been found in Finland (Nelson et al. 2011) and recently in Sweden and Norway (Munyaneza and Nelson, unpublished data). A new and fourth Lso haplotype referred to as " $D$ " was very recently described from infected carrots and the psyllid B. trigonica in Spain and the Canary Islands (Munyaneza and Nelson, unpublished data). The four haplotypes are not yet known to elicit biological differences in the plant or insect hosts. These apparently stable haplotypes suggest separate long-lasting populations of the bacterium. Furthermore, a study on the genetic diversity of Lso strains using simple sequence repeat (SSR) markers identified two major lineages of this bacterium in the United States and only one lineage in Mexico (Lin et al. 2012).

Little is known on the effects of environmental conditions on development of Lso in plant and insect hosts.
Temperature has been shown to have a significant effect on the development of this bacterium in potato plants (Munyaneza et al. 2012a). Compared to liberibacters associated with citrus greening disease, Lso appears to be heat-sensitive, and seems not to tolerate temperatures above $32{ }^{\circ} \mathrm{C}$ (Munyaneza et al. 2012a). Additionally, temperatures at or below $17{ }^{\circ} \mathrm{C}$ may significantly slow, but not prevent, Lso development in potato (Munyaneza et al. 2012a). The optimum development of Lso and ZC symptoms in potato plants was observed at a daily temperature regime of $27-32{ }^{\circ} \mathrm{C}$. At the higher daily temperature regimes of $32-35$ and $35-40{ }^{\circ} \mathrm{C}$, no Lso was detected in potato plants inoculated with the bacterium using insects and no ZC symptom development occurred (Munyaneza et al. 2012a). The vector of the pathogen in the Americas and New Zealand, B. cockerelli, appears to have similar temperature preferences (Pletsch 1947; Abdullah 2008; Yang et al. 2010a). Studies have also shown that Lso within the adult potato psyllid is sensitive to high and low temperatures, with the highest bacterial titers occurring at approximately $28^{\circ} \mathrm{C}$ (Rush et al. 2010). This temperature is very similar to the preferred optimum temperature $\left(27{ }^{\circ} \mathrm{C}\right)$ for potato psyllid reproduction and liberibacter development in the plant (Munyaneza 2010; Munyaneza et al. 2012a). It has also been determined that Lso titer does not differ between males and females, exists at very low titer in fifth-instar nymphs, and increases with age of the adult psyllid (Rush et al. 2010). Furthermore, it has been shown that Lso has a negative effect on population growth rate of $B$. cockerelli, at least when the psyllid is reared on tomato (Nachappa et al. 2012).

\section{Diagnosis and Detection}

The characteristic plant symptoms of Lso infection in both potatoes and other solanaceous species resemble those caused by phytoplasmas: plant stunting, erectness of new foliage, chlorosis and purpling of foliage with basal cupping of leaves, upward rolling of leaves throughout the plant, shortened and thickened terminal internodes resulting in plant rosetting, enlarged nodes, axillary branches, leaf scorching, disruption of fruit set, and production of numerous, small, misshaped, and poor quality fruits (Liefting et al. 2008b; Liefting et al. 2009a; McKenzie and Shatters 2009; Munyaneza et al. 2009c,d; Secor et al. 2009; Brown et al. 2010; French-Monar et al. 2010; Crosslin et al. 2010). Symptoms in carrots infected with Lso include leaf curling, yellowish, bronze and purplish discoloration of leaves, stunting of the carrot shoots and roots, and proliferation of secondary roots (Munyaneza et al. 2010c,d; 2012b,c; Alfaro-Fernández et al. 2012a,b). Symptoms in carrots collectively resemble those caused by leafhopper-transmitted 
phytoplasmas and Spiroplasma citri (Font et al. 1999; Lee et al. 2006; Cebrián et al. 2010; Munyaneza et al. 2011c).

The genome of Lso isolated from zebra chip-infected potatoes has recently been sequenced and published (Lin et al. 2011b). Detection methods for Lso have been developed and include both conventional and quantitative realtime polymerase chain reaction (PCR) (Hansen et al. 2008; Crosslin and Munyaneza 2009; Li et al. 2009; Liefting et al. 2008a, 2009a; Lin et al. 2009; Wen et al. 2009; Munyaneza et al. 2010d; Crosslin et al. 2011b; Lin et al. 2011a; Pitman et al. 2011; Ravindran et al. 2011a, b; Wen et al. 2011). Detection of the bacterium in psyllids by PCR is relatively straightforward (Munyaneza et al. 2010d; Crosslin et al. 2011b). Uneven distribution and variation in Lso titer in different parts of infected potato plants have been observed, making detection by PCR sometimes inconsistent (Crosslin and Munyaneza 2009; Li et al. 2009; Buchman et al. 2011a; Levy et al. 2011). Development of better and more accurate detection methods by PCR is currently underway. Mixed infections of Lso and phytoplasmas have been reported in potato (Liefting et al. 2009b; Munyaneza unpublished data) and carrot (Munyaneza et al. 2011c), while mixed infections of Lso, phytoplasmas, and $S$. citri have been detected in carrots in the Mediterranean region (Alfaro-Fernández et al. 2012a).

\section{Insect Vector: Bactericera cockerelli}

The potato/tomato psyllid, Bactericera $(=$ Paratrioza) cockerelli (Šulc) (Hemiptera: Triozidae) was linked to ZC for the first time in 2007 by Munyaneza et al. (2007a, b), preceding the identification of Lso as the putative causal agent of the disease (Hansen et al. 2008; Liefting et al. 2008a; Butler and Trumble 2012a). The psyllid feeds upon the phloem using piercing-sucking mouthparts. The potato psyllid is known as a serious and economically important pest of potatoes, tomatoes, and other solanaceous crops in the western United States, southern Canada, Mexico, Central America and New Zealand.

\section{Identification and Description}

A detailed diagnostic description of $B$. cockerelli and other potato psyllids around the world was recently provided by Halbert and Munyaneza (2012). Cicero et al. (2009) gave a detailed description of the digestive system of this psyllid in relation to potential location and movement of Lso in the insect body. Adult potato psyllids (Fig. 5) are small, measuring about $2.5 \mathrm{~mm}$ long, and resemble tiny cicadas, largely because they hold their wings roof-like (Wallis 1955). Body color ranges from pale green at emergence to dark green or brown within 2-3 days, and eventually becomes gray or black thereafter. Prominent white or yellow lines are found on the head and thorax, and dorsal whitish bands are located on the first and terminal abdominal segments. These white markings are distinguishing characteristics of the psyllid, particularly the broad, transverse white band on the first abdominal segment and the inverted V-shaped white mark on the last abdominal segment (Pletsch 1947; Wallis 1955). Adults are active in contrast to the largely sedentary nymphal stages. The adult psyllids are good fliers and may jump readily when disturbed. Adult longevity ranges from 20 to 62 days, and females usually live two to three times longer than males, depending on host plant (Pletsch 1947; Abernathy 1991; Abdullah 2008; Yang and Liu 2009; Yang et al. 2010a). The oviposition period may extend to almost 50 days, with an average fecundity of 300-500 eggs per female over her lifetime (Knowlton and Janes 1931; Pletsch 1947; Abdullah 2008; Yang and Liu 2009; Yang et al. 2010a).

The light to dark yellow or orange eggs of $B$. cockerelli (Fig. 6) are deposited singly, principally on the lower surface of leaves and near the leaf edge. Often, females will lay numerous eggs on a single leaf (Pletsch 1947; Wallis 1955; Halbert and Munyaneza 2012). The eggs are mounted on short stalks and hatch 3-7 days after oviposition (Pletsch 1947; Wallis 1955; Capinera 2001; Abdullah 2008; Yang et al. 2010a; Butler and Trumble 2012a; Halbert and Munyaneza 2012). The orange or yellowish-green nymphs (Fig. 7) are flat with a scale insect-like appearance (Halbert and Munyaneza 2012; Butler and Trumble 2012a). There are five nymphal instars, of similar appearance other than size (Rowe and Knowlton 1935; Pletsch 1947; Wallis 1955). The eyes are reddish and quite prominent. A short fringe of wax filaments is present along the lateral margins of the body. During the third instar, the wing pads, light in color, are evident and become more pronounced with each subsequent molt. Potato psyllid nymphs may be confused with the nymphs of whiteflies, although only the former move when disturbed. Because nymphs prefer sheltered and shaded locations, they are mostly found on the lower surfaces of leaves and usually remain sedentary during their development. Total nymphal development time depends on temperature and host plant and has been reported to have a range of 12 to 24 days (Knowlton and Janes 1931; Abdullah 2008; Yang and Liu 2009; Yang et al. 2010a). Both nymphs and adults produce large quantities of whitish excrement particles.

\section{Geographical Distribution}

The potato psyllid is native to North America and occurs mainly in the Rocky Mountain region of the United States and Canada, from Colorado, New Mexico, Arizona, and Nevada, north to Utah, Wyoming, Idaho, Montana, Alberta and Saskatchewan (Pletsch 1947; Wallis 1955; Cranshaw 1993; Ferguson and Shipp 2002). This insect pest is 
Fig. 5 Adult potato psyllids with characteristic whitish bands on the abdomen and white or yellow lines on the head and thorax
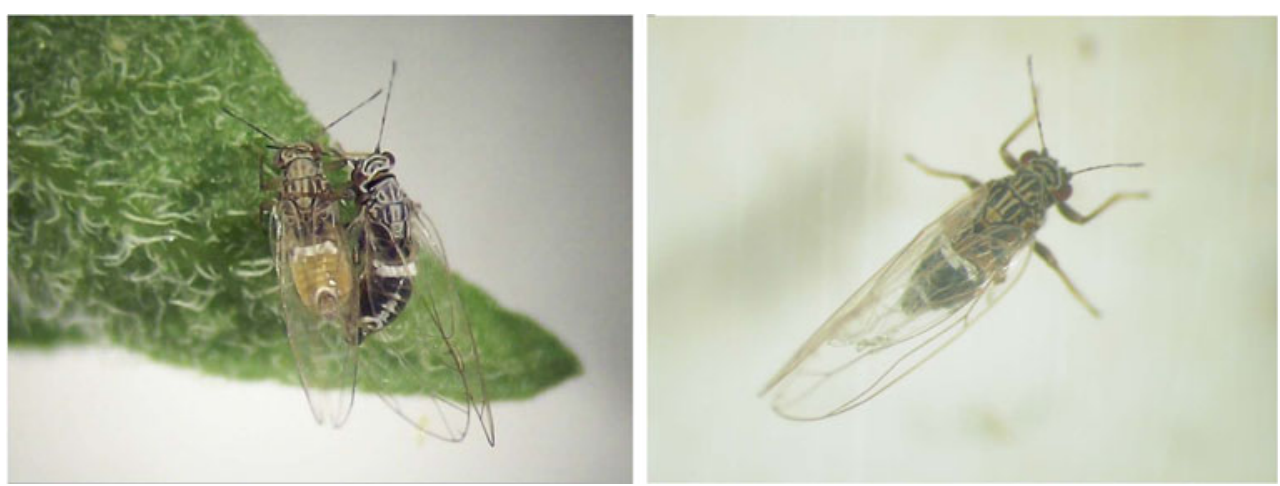

common in southern and western Texas and has also been documented in Oklahoma, Kansas, Nebraska, South Dakota, North Dakota, Minnesota and as far west as California and British Columbia. Interestingly, the psyllid has not been documented east the Mississippi River (Richards and Blood 1933; Pletsch 1947; Wallis 1955; Cranshaw 1993; Capinera 2001; Butler and Trumble 2012a). Contrary to reports in the older literature (Pletsch 1947; Wallis 1955; Cranshaw 1993, 2001), the potato psyllid does indeed occur in Washington and Oregon, where it usually colonizes potato fields in late June and early July (Munyaneza et al. 2009a; Munyaneza 2010; Crosslin et al. 2012a). There are also indications that the psyllid may overwinter in the Pacific Northwest (Jensen 2012). The potato psyllid also occurs in Mexico and Central America, including Guatemala and Honduras (Pletsch 1947; Wallis 1955; Rubio-Covarrubias et al. 2006; Trumble 2008, 2009; Crosslin et al. 2010; Espinoza 2010; Munyaneza 2010; Rehman et al. 2010; Rubio-Covarrubias et al. 2011a), and most recently was reported from Nicaragua (Nicaragua-MAGFOR 2012). The psyllid was accidentally introduced into New Zealand, apparently sometime in the early 2000s (Gill 2006; Liefting et al. 2009a; Teulon et al. 2009; Thomas et al. 2011), and is now established on both North and South Island where it causes extensive damage to the potato, tomato, pepper, and tamarillo crops (Teulon et al. 2009). It is not clear how the insect arrived in New Zealand;

Fig. 6 Eggs of potato psyllid however, it has been suggested that the psyllid was introduced into the country from the western United States, probably through smuggled primary host plant material (Thomas et al. 2011).

\section{Biology}

Bactericera cockerelli is found primarily on plants within the family Solanaceae, but also attacks, reproduces, and develops on a variety of cultivated and weedy plant species (Essig 1917; Knowlton and Thomas 1934; Pletsch 1947; Jensen 1954; Wallis 1955; Butler and Trumble 2012a), including crop plants such as potato, tomato, pepper, and eggplant, and non-crop species such as nightshade (Solanum spp.), groundcherry (Physalis spp.), and matrimony vine (Lycium spp.). Adults have been collected from plants in numerous plant families, including the Pinaceae, Salicaceae, Polygonaceae, Chenopodiaceae, Brassicaceae, Asteraceae, Fabaceae, Malvaceae, Amaranthaceae, Lamiaceae, Poaceae, Menthaceae, and Convolvulaceae, but this is not an indication of the true host range of this psyllid (Pletsch 1947; Wallis 1955; Cranshaw 1993), as these plants rarely if ever support reproduction and growth. Besides solanaceous species, $B$. cockerelli has been shown to reproduce and develop on some species in the family Convolvulaceae, including field bindweed (Convolvulus spp.) and sweet potato (Ipomoea
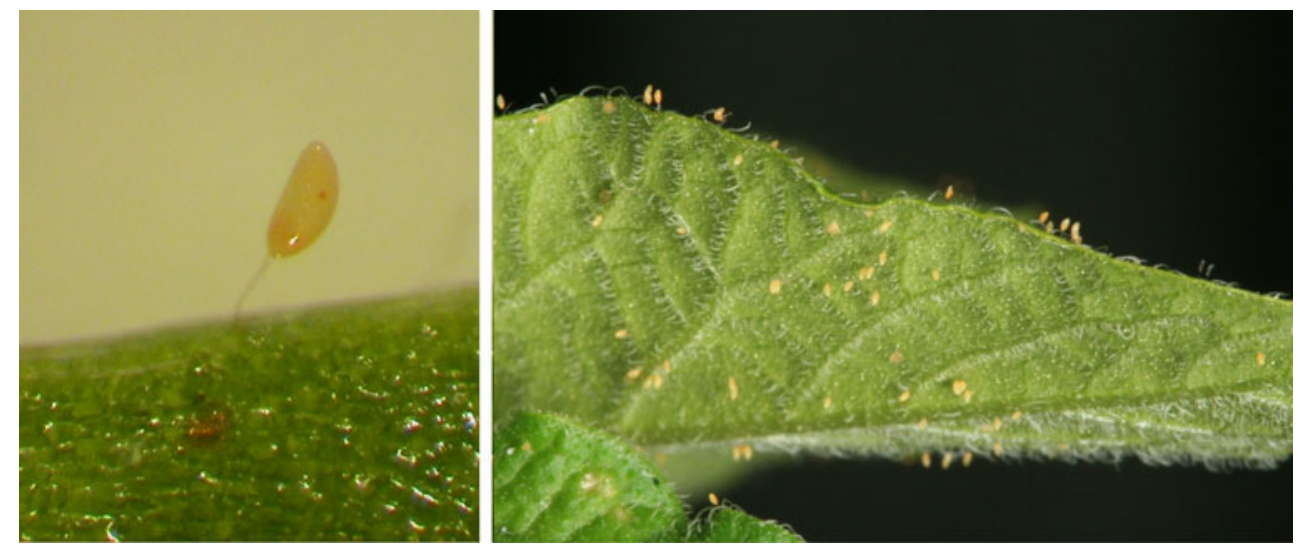
Fig. 7 Nymphs of potato psyllid: second to fourth instars (a) and fifth instar with evident wing pads (b)
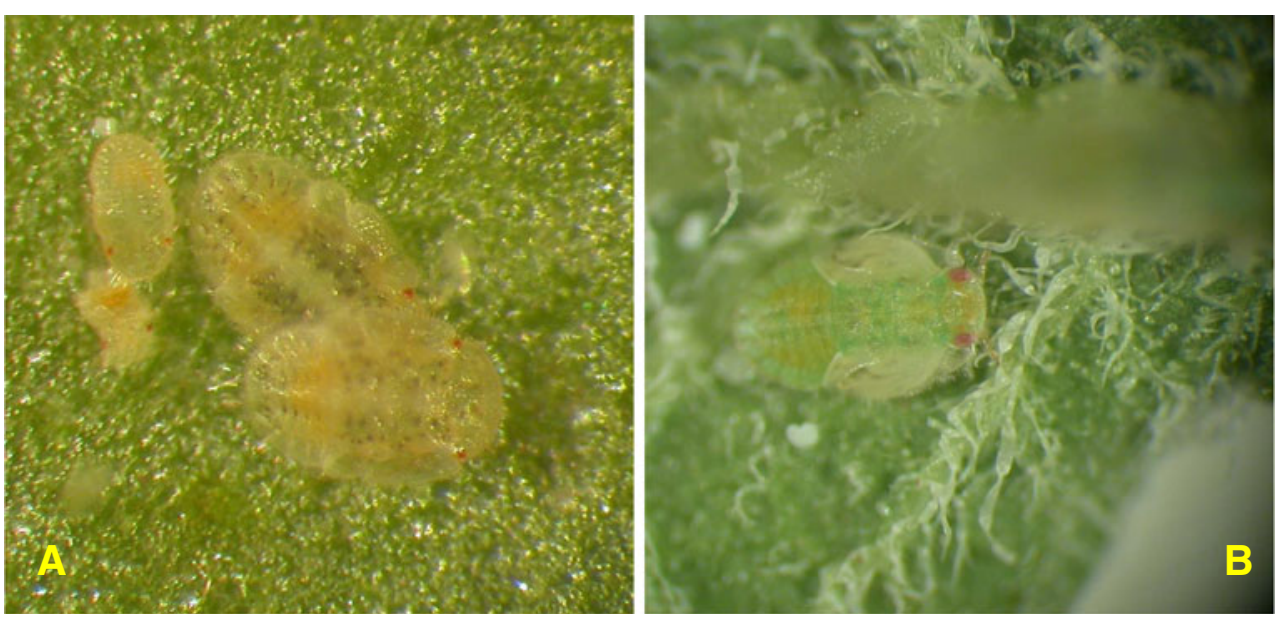

batatas) (Knowlton and Thomas 1934; List 1939; Wallis 1955; Puketapu and Roskruge 2011; Munyaneza, unpublished data). Interestingly, numerous attempts to inoculate field bindweed and sweet potato with Lso-infected psyllids were unsuccessful, suggesting that members of Convolvulaceae are not suitable hosts to Lso, although they can support reproduction and development of its insect vector (Munyaneza, unpublished data).

Weather is an important element governing the biology of $B$. cockerelli and its damage potential. The potato psyllid seems to be adapted for warm but not hot temperatures. Cool weather during migrations, or at least the absence of elevated temperatures, has been associated with outbreaks of this insect (Pletsch 1947; Wallis 1955; Capinera 2001; Cranshaw 2001). Optimum psyllid development occurs at approximately $27{ }^{\circ} \mathrm{C}$, whereas oviposition, hatching, and survival are reduced at $32{ }^{\circ} \mathrm{C}$ and cease at $35{ }^{\circ} \mathrm{C}$ (List 1939; Pletsch 1947; Wallis 1955; Cranshaw 2001; Abdullah 2008; Yang and Liu 2009; Yang et al. 2010a; Butler and Trumble 2012a). A single generation may be completed in three to five weeks, depending on temperature. The number of generations varies considerably among regions, usually ranging from three to seven. However, once psyllids colonize an area, prolonged oviposition causes the generations to overlap, making it difficult to distinguish between generations (Pletsch 1947; Wallis 1955; Munyaneza et al. 2009a). Both adults and nymphs are very cold tolerant, with nymphs surviving temporary exposure to temperatures of $-15^{\circ} \mathrm{C}$ and $50 \%$ of adults surviving exposure to $-10{ }^{\circ} \mathrm{C}$ for over $24 \mathrm{~h}$ (Henne et al. 2010a).

In North America, driven primarily by wind and hot temperatures in late spring, $B$. cockerelli annually migrates from its overwintering and breeding areas in southern and western Texas, southern New Mexico, Arizona, California, and northern Mexico (Pletsch 1947; Wallis 1955). The migration occurs especially through the midwestern states and Canadian provinces along the Rocky Mountains (Romney 1939; Pletsch 1947; Jensen 1954; Wallis 1955). In these regions, damaging outbreaks of potato psyllid in potatoes and tomatoes occurred at regular intervals beginning in the late1800s and extending into the 1940s (List 1939; Wallis 1946; Pletsch 1947). In more recent years, psyllid outbreaks have also occurred in regions outside of the midwestern United States, including in southern California, Baja California, Oregon, Washington, Idaho, and Central America (Trumble 2008, 2009; Munyaneza et al. 2009a; Wen et al. 2009; Crosslin et al. 2010; Munyaneza 2010; Espinoza 2010; Butler and Trumble 2012a; Crosslin et al. 2012a,b; Nicaragua-MAGFOR 2012).

Outbreaks in Baja California and coastal California led to the discovery that potato psyllid in those regions is genetically distinct from psyllids that overwinter in southern Texas and eastern Mexico, suggesting the existence of two different potato psyllid biotypes referred to elsewhere as "western and central" biotypes (Liu et al. 2006; Jackson et al. 2009). The western biotype differs from southern Texas populations in several life history traits (Liu and Trumble 2007) and possibly overwinters in geographic areas different from regions used by psyllids of the midwestern United States (Trumble 2008). Following the 2011 reports of ZC in Idaho, Oregon, and Washington (Hamm et al. 2011; Nolte et al. 2011; Crosslin et al. 2012a, b), a genetic study by Swisher et al. (2012) using high resolution melting analysis of the mitochondrial Cytochrome $\mathrm{C}$ Oxidase subunit I-like gene of $B$. cockerelli led to the identification of a third biotype (referred to as "northwestern haplotype"), so far known only from the Pacific Northwest. This northwestern potato psyllid biotype is genetically different from the central and western biotypes (Swisher et al. 2012). Interestingly, ZC has yet to be shown that it is associated with this northwestern psyllid biotype (Swisher et al. 2012).

Information about migration of $B$. cockerelli within Mexico and Central America is lacking. In the southwestern United States, potato psyllids reappear in overwintering areas between October and November, presumably dispersing southward from northern locations (Capinera 2001); however, their origin has not been determined. In countries and regions 
where there are no significant seasonal changes during the winter, temperatures are relatively cool, and where suitable host plants are available (e.g., Mexico, Central America), the potato psyllid is able to reproduce and develop all year round (Espinoza 2010; Rubio-Covarrubias et al. 2011b).

In an effort to identify and develop a sex pheromone and other attractants that can be used to develop improved integrated pest management programs for B. cockerelli, reproductive biology and the role of chemical signals in sex attraction in the potato psyllid were studied by Guédot et al. (2010, 2012). It was determined for the first time that the potato psyllid possesses a female-produced pheromone that attracts males (Guédot et al. 2010). Guédot et al. (2012) also showed that adult potato psyllids reach reproductive maturity within $48 \mathrm{~h}$ post-eclosion, with females being mature on the day of eclosion and males at one day posteclosion. In addition, oviposition generally began two days after mating but was delayed when females mated within two days post-eclosion.

Identification of symbionts associated with $B$. cockerelli is currently being investigated. "Candidatus Carsonella ruddii', the obligate and primary endosymbiont of psyllids has been confirmed in the potato psyllid (Nachappa et al. 2011; Hail et al. 2012). Beside Lso, several other secondary endosymbionts associated with the potato psyllid have recently been reported and include the bacteria Wolbachia, Acinetobacter, Methyllibium, Rhizobium, Gordonia, Mycobacterium, and Xanthomonas (Nachappa et al. 2011; Hail et al. 2012; Butler and Trumble 2012a). Currently, little information is available on the interactions and symbiont relationship between these microorganisms and the potato psyllid.

\section{Pest Significance of Bactericera cockerelli and Candidatus Liberibacter solanacearum}

The potato psyllid is one of the most destructive potato pests in the western hemisphere (Cranshaw 1993; Butler and Trumble 2012a). It was recognized by the early 1900 s that $B$. cockerelli had the potential to be an explosive and injurious insect (Šulc 1909; Compere 1915, 1916; Essig 1917). By the 1920s and 1930s, B. cockerelli had become a serious and destructive pest of potatoes in many parts of the southwestern United States, giving rise to the description of a new disease that became known as 'psyllid yellows' (Richards 1928, 1931, 1933; Binkley 1929; Richards and Blood 1933; List and Daniels 1934). Historically, the extensive damage to solanaceous crops observed during the potato psyllid outbreaks in the early 1900s is thought to have been due to $B$. cockerelli's association with the psyllid yellows disease, presumably caused by a toxin that is transmitted during the insect's feeding activities, especially by nymphs
(Eyer and Crawford 1933; Eyer 1937). However, this toxin has yet to be demonstrated and identified.

Above-ground plant symptoms of psyllid yellows are similar to those of $\mathrm{ZC}$ and potato purple top disease and include arrested growth, erectness of new foliage, chlorosis and purpling of new foliage with basal cupping of leaves, upward rolling of leaves, shortened and thickened terminal internodes resulting in rosetting, enlarged nodes, axillary branches, and aerial potato tubers (List 1939; Pletsch 1947; Daniels 1954; Wallis 1955; Arslan et al. 1985; Cranshaw 1993; Butler and Trumble 2012a). Below-ground symptoms include setting of excessive numbers of tiny misshaped potato tubers, production of chain tubers, and early breaking of tuber dormancy (Richards and Blood 1933; Eyer 1937; List 1939; Pletsch 1947; Wallis 1955; Arslan et al. 1985; Cranshaw 1993). However, unlike in ZC-infected plants, tubers affected by psyllid yellows do not develop any necrotic symptoms, whether raw or processed into fried chips or fries. A detailed review of phenotypic and etiological differences between psyllid yellows and ZC diseases of potato is provided by Sengoda et al. (2010). In areas where outbreaks of psyllid yellows have occurred, the disease was often present in $100 \%$ of plants in affected fields, with yield losses exceeding $50 \%$ in some areas (Pletsch 1947; Cranshaw 1993).

In recent years, potato, tomato, and pepper growers in a number of geographic areas of the world have suffered extensive economic losses associated with outbreaks of potato psyllids (Trumble 2008, 2009; Munyaneza et al. 2007a,b; 2008; 2009b,c,d; Liefting et al. 2008a,b; 2009a; Secor et al. 2009; Crosslin et al. 2010; Munyaneza 2010; Rehman et al. 2010; Butler and Trumble 2012a; Crosslin et al. 2012a,b; Halbert and Munyaneza 2012; NicaraguaMAGFOR 2012). The severe damage to these solanaceous crops is mainly due to the recent association of the potato psyllid with Lso. In the United States, ZC has moved steadily northward following its initial appearance in northern Mexico in 1994, arriving as far north as potato fields in Wyoming by 2007. Despite annual psyllid infestations in the Pacific Northwest, ZC was not previously thought to have expanded beyond its 2007 range into the Pacific Northwest region of the United States. That changed dramatically in September 2011, when ZC was widely reported in potato fields in Washington, Idaho, and Oregon (the three states responsible for over $50 \%$ of the total United States potato production), leading to losses in the millions of dollars (Hamm et al. 2011; Nolte et al. 2011; Crosslin et al. 2012a,b; Rondon et al. 2012). This event not only marks a troubling expansion of $\mathrm{ZC}$, it also poses a major threat to a significant acreage of the United States potato production. The source of Lso-infected psyllids responsible for the ZC outbreak in the Pacific Northwest in 2011 is not known but recent studies on genetic analysis of psyllid populations collected in the region in 2011 (Swisher et al. 2012), 
coupled with air parcel trajectory analysis (Workneh et al. 2011) suggest that the psyllids in the infested regions of the Pacific Northwest were primarily or exclusively of the western biotype, most likely originating from the southern California area and/or northwest Mexico, and not from the south central United States.

In a number of potato growing regions where the potato psyllid occurs, entire fields have been abandoned because of ZC (Secor and Rivera-Varas 2004; Munyaneza et al. 2007a; Crosslin et al. 2010; Munyaneza 2010) (Fig. 8). Studies conducted under controlled field cage conditions in Texas and Washington by Munyaneza et al. (2008, 2011d) reported yield losses due to psyllids and ZC damage ranging from 43 to $93 \%$ in several commercial potato varieties. The potato industry in Texas estimates that ZC could affect over $35 \%$ of the potato acreage in the state, with potential losses annually to growers exceeding US\$25 million dollars (CNAS 2006; Rosson 2009). Control costs for the potato psyllid have dramatically increased. For example, costs to control the psyllid averaged US\$300 (ranging from US\$170 to $\$ 590)$ per acre in the southwestern and central United States from 2009 to 2011 (Guenthner and Greenway 2010; Guenthner et al. 2011). During this period, estimates of yield loss due to $\mathrm{ZC}$ and psyllids in the region ranged from 0.5 to $75 \%$ (Guenthner and Greenway 2010; Guenthner et al. 2011). In addition, potato processing quality was affected severely. Since arriving in New Zealand in 2006, the potato psyllid and Lso have cost the potato industry at least US\$96 million, with US\$22.5 million in the 2010-2011 growing season alone (Ogden 2011). ZC has caused devastating epidemics in potato growing area of northern Mexico, where up to $60 \%$ of potato crops have been affected (Galviz et al.
2010; Rubio-Covarrubias et al. 2011a,b). Insecticide applications targeting potato psyllid have increased about $300 \%$ in some areas of Mexico (Rubio-Covarrubias et al. 2011b). The potato psyllid was first detected in Honduras in 2002 and has since spread to the entire potato growing region of the country, causing significant losses and an increase in insecticide use (Espinoza 2010). In 2012, severe ZC outbreaks were reported for the first time from Nicaragua (Nicaragua-MAGFOR 2012), causing significant potato crop losses and prompting extensive use of insecticides.

Finally, quarantine issues have begun to emerge in potato psyllid-affected regions because some countries now require that shipments of solanaceous crops from certain growing regions must be free of the psyllid and be tested for Lso before the shipments are allowed entry into the countries (Crosslin et al. 2010). In 2012, Costa Rica temporarily banned all imports of potato upon the discovery of the potato psyllid and ZC in neighboring Nicaragua (Costa Rica-MAG 2012).

\section{Zebra Chip Transmission, Biology, and Epidemiology}

Little is known about vector-pathogen-plant interactions in the ZC/potato psyllid complex, especially mechanisms by which the potato psyllid acquires and transmits Lso to potato and other host plants, and how transmission leads to development of ZC. This basic knowledge about these interactions is essential for devising effective management strategies. Specifically, information is needed on how psyllids acquire and transmit Lso, latency period of Lso, densities and
Fig. 8 A potato field severely infected with zebra chip disease in the Columbia Basin of Washington in September of 2011

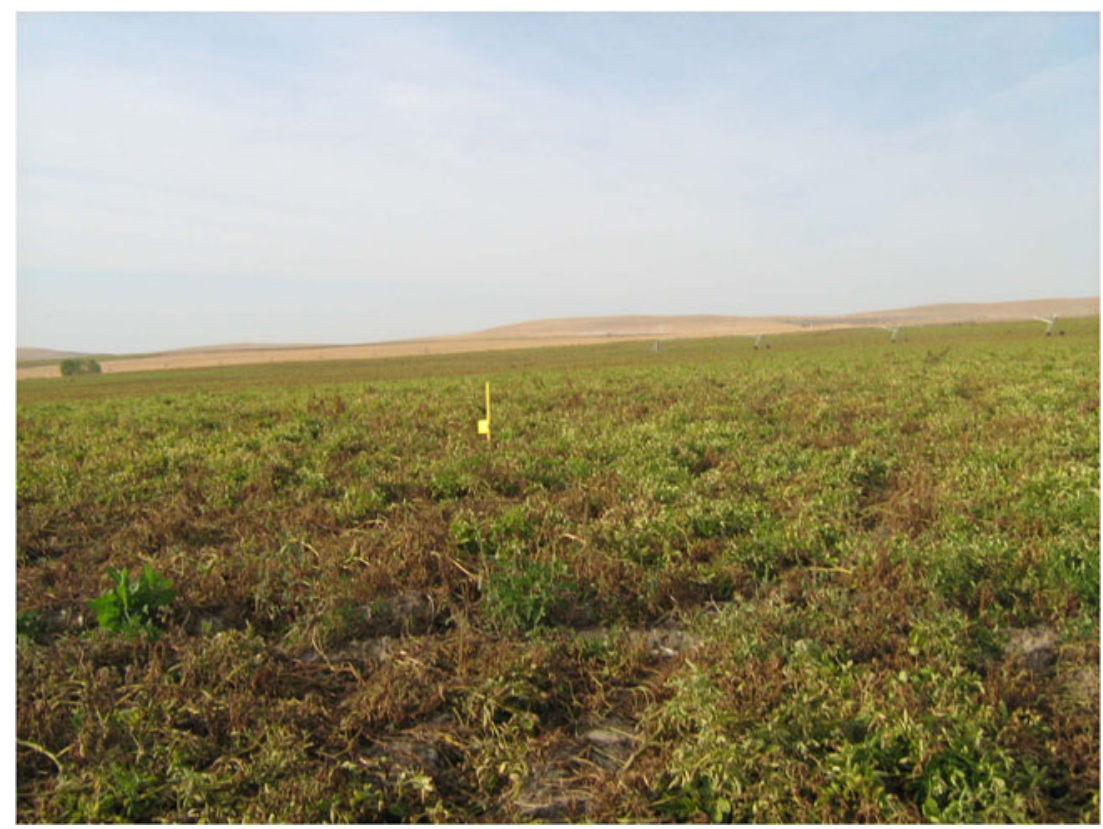


feeding durations needed to transmit Lso, and physiology of the bacterium in the plant.

To increase the understanding of pathogen transmission by the potato psyllid, biology and feeding behavior of this insect vector were studied by Pearson et al. (2010). Using Electrical Penetration Graph (EPG) technology, Pearson et al. (2010) analyzed stylet penetration behavior of the potato psyllid while feeding on potato (cv. Atlantic, a chipping variety highly susceptible to ZC). Feeding patterns referred to as 'waveforms' were identified and then defined using light microscopy of salivary sheath termini in plant tissue after probes were artificially terminated. Four main probing activities were identified and characterized, including stylet pathway activities representing the secretion of the salivary sheath while probing in the vicinity of epidermal and parenchyma cells $(C)$, ingestion from xylem tissue $(\mathrm{G})$, salivation prior to phloem ingestion (E1), and phloem ingestion (E2). It is thought that during the duration of waveform E2 the pathogen is most likely acquired from an infected host plant, whereas the pathogen is most likely inoculated into the host plant via egestion occurring when the vector is salivating during the phase corresponding to waveform E1 (Pearson et al. 2010). Furthermore, these waveforms are useful in screening plants for host plant resistance to either direct feeding or Lso transmission by psyllids and to assess effectiveness and mode of action of insecticides used to control the potato psyllid (Butler et al. 2012).

The primary way that potato psyllids acquire and spread Lso is by feeding on infected plants. Results of preliminary studies indicate that the Lso latent period (time that elapses from initial Lso acquisition to the ability to transmit the pathogen) in the psyllid is about two weeks after an acquisition period of $8-24 \mathrm{~h}$ on Lso-infected potato plants (Munyaneza and Sengoda, unpublished data). This latent period has been observed to be shorter when psyllids have fed on Lso-infected tomato plants, apparently due to much higher Lso titer in tomato than potato (Munyaneza and Sengoda, unpublished data). The bacterium is also transmitted transovarially in the psyllid at a relatively high rate (Hansen et al. 2008; Munyaneza, unpublished data). In addition, Lso can be transmitted to potato through grafting (Crosslin and Munyaneza 2009; Secor et al. 2009), although it has been shown that Lso is transmitted to potato leading to ZC development more rapidly by psyllid activities than by grafting (Sengoda et al. 2010; Buchman et al. 2011a,b; 2012) .

Buchman et al. (2011b) demonstrated that adult potato psyllids were highly efficient vectors of Lso, and that nymphs were less efficient than adults. The authors also showed that exposure of a healthy potato plant to 20 Lsoinfected adult potato psyllids for a period as short as one hour resulted in ZC symptom development, whereas a single adult potato psyllid was capable of inoculating Lso to potato within a period as short as six hours and leading to development of ZC (Buchman et al. 2011b). Moreover, results of their study showed that feeding period had little influence on overall ZC disease incidence, severity, and resulting yield loss. Furthermore, Buchman et al. (2011a) discovered that a single Lso-infective adult psyllid was as damaging as 25 infective psyllids per plant.

Buchman et al. (2012) determined how rapidly ZC symptoms develop in potato tubers following plant exposure to Lso-infected potato psyllids under field conditions, and assessed how the disease affects the yield and tuber processing quality. ZC symptoms developed in potato tubers about three weeks following exposure of plants to psyllids. Interestingly, the symptoms developed in tubers before they were observed in the above-ground parts of plants. It was also shown that tuber development ceased upon the onset of ZC symptoms, resulting in substantial yield loss (Buchman et al. 2012). It is important to note that if the plants are infected prior to the tuber initiation stage, the plants die quickly and also fail to produce tubers. In addition, Buchman et al. (2012) reported that levels of tuber solids decreased as soon as initial disease symptoms were observed, whereas reducing sugar levels in tubers increased dramatically, significantly lowering potato processing quality. Similar observations were made by Levy et al. (2011) while examining patterns of Lso translocation through phloem in potato and tomato plants under greenhouse conditions. Levy et al. (2011) found that Lso was detectable in tomato and potato plants two to three weeks after plant exposure to Lso-infected potato psyllids, most frequently in the upper- and middletier leaves. They also reported that Lso was detected in potato leaves of a second and non-inoculated stem when the stems remained joined via the mother tuber.

Lso has been shown to severely disrupts carbohydrate flow in potato plants, leading to $\mathrm{ZC}$ symptoms in the tubers. Buchman et al. (2011a, 2012) showed that ZC infection resulted in overall high glucose and sucrose levels compared with uninfected tubers. Similar conclusions regarding production of high levels of both sugars in ZC-infected tubers were reached earlier by Gao et al. (2009). It has been suggested that the necrotic flecking and streaking of the medullary ray tissue symptoms in ZC-infected tubers is related to darkening of the resulting processed chips or fries due to elevated sugar levels which caramelize when tuber slices are fried ("Maillard Reaction"). Miles et al. (2010) has shown that cell death is also associated with ZC symptoms in both raw and fried potato tubers. Navarre et al. (2009) reported high levels of aromatic amino acids and phenolic compounds in extracts from ZC-symptomatic potato tubers. During Navarre et al. (2009) study, tyrosine concentrations increased over 8-fold in ZC-symptomatic tubers, suggesting that the dramatic increase in this amino acid may significantly contribute to the browning observed in $\mathrm{ZC}$-infected 
tubers. Salicylic acid, a key regulator of plant defenses, was also shown to be present at very high concentrations in ZCinfected tubers, which is consistent with what would be expected from tubers mounting a defense response to a pathogen (Navarre et al. 2009). On the other hand, Wallis and Chen (2011) determined that ZC-infected tubers possessed significant high levels of peroxidase, polyphenol oxidase, chitinase, and $\beta$-1,3-glucanase. The observed increases in phenolics, amino acids, and defense-associated enzymes were significantly correlated with ZC symptom severity, but uncorrelated with Lso titers. Wallis and Chen (2011) confirmed the hypothesis of Navarre et al. (2009) that increased phenolic and polyphenol oxidase levels in ZC-infected potatoes result in increased browning of freshly cut tubers, whereas increased amino acid levels result in increased browning when ZC-tuber slices are fried. Similarly, Nissinen et al. (2012) reported significant increases in concentrations of phenolic compounds and some amino acids in roots of carrot plants attacked by Lso-infected T. apicalis. Furthermore, Miles et al. (2009) showed that there were significant differences in mineral content between ZCinfected and ZC-free potato tubers.

Alvarado et al. (2012) found that ZC-infected potato stems appear to be programmed to exhibit tuber-like physiological properties. It was determined that compared to healthy plants, stems of ZC-infected plants accumulate starch and proteins, including gene expression regulatory factors (e.g., cyclophilin) and tuber storage proteins (e.g., patatins). This abnormal starch and protein accumulation in stems may explain formation of aerial tubers and fleshy and succulent stems by ZC-infected plants, instead of the characteristic hollow and brittle stems of healthy plants. Furthermore, Alvarado et al. (2012) discovered that the total phenolic content in ZC-affected stems was elevated twofold, and levels of polyphenol oxidase enzyme were also high, both serving to explain the rapid brown discoloration of air-exposed damaged tissue observed in ZC-infected potato plants and tubers.

It has been suggested that Lso manipulates plant signaling and defensive responses to benefit itself and the potato psyllid, its insect vector, on their host plants. Using tomato as a model, Casteel et al. (2012) showed that feeding by different life stages of the potato psyllid infected with Lso induced tomato genes regulated by jasmonic acid and salicylic acid, including Allene oxidase synthase, Proteinase inhibitor 2, Phenylalanine ammonia-lyase 5, and Pathogenesis-related protein 1 . Gene induction was significantly more pronounced in life stages with lower Lso titer (younger nymphs) than those with higher Lso titer (older nymphs and adults). Interestingly, inoculation of Lso without insect hosts through grafting suppressed accumulation of these defense transcripts. Collectively, the results of Casteel et al. (2012) study demonstrated that the potato psyllid may influence plant defense responses by its vectoring of Lso during feeding and that the bacterium then causes a substantial reduction of jasmonic acid/ethylene- and salicylic acid-regulated plant defense transcripts.

Although the impact of ZC has been substantially documented for processing and table potatoes, little is known on ZC-tuber transmission and the impact of this disease and its insect vector on quality of potato seed. ZC-infected potato tubers potentially being a source of the disease spread is a major concern and could be a threat to national and international trade of fresh and seed potatoes. In a study conducted in the United States, Henne et al. (2010c) showed that about $44 \%$ of ZC-infected tubers remained viable under greenhouse conditions, but produced hair sprouts and weak plants that died prematurely; a low percentage of plants from ZCinfected tubers tested positive for Lso. Henne et al. (2010c) concluded that in areas where ZC is currently established, plants produced by ZC-infected seed tubers do not contribute significantly to $\mathrm{ZC}$ incidence and spread within potato fields. Studies conducted in New Zealand by Pitman et al. (2011) and Berry et al. (2011) reported a rate of potato plant emergence from tubers testing positive for Lso by PCR, but not exhibiting typical ZC symptoms, as high as $90 \%$. This potato plant emergence resulted in production of marketable tubers, although plant growth and potato yield were significantly reduced. Production of ZC-infected daughter tubers during Pitman et al. (2011) and Berry et al. (2011) studies was however very negligible.

As a follow up to $\mathrm{ZC}$ transmission through potato tubers, Munyaneza et al. (2011b) examined the impact of Lso-free and Lso-infected psyllids on plant emergence, viability, yield, and ZC incidence in nine commercial potato varieties important to the United States under controlled field cage conditions, over two years and in Washington and Texas, two different and distant locations. Potato plants were continuously exposed to either Lso-free or Lso-infected psyllids under controlled field cage conditions and, at harvest, the tubers were collected and planted in field cages the following season. Plant emergence for tubers produced by psyllidfree plants (controls) and those continually exposed to Lsofree psyllids (i.e., psyllid yellows) was $100 \%$ two to three weeks after planting and all the plants produced ZC-free tubers. No difference in yield was observed between plants from psyllid yellows-affected tubers and those produced by psyllid-free plants. In contrast, plant emergence for ZCinfected tubers from plants that were previously exposed to Lso-infected psyllids ranged from $0-22.2 \%$ and occurred between five and 11 weeks after planting. Although these emerging ZC-infected tubers initially produced hair sprouts which later turned into weak plants, none of the plants tested positive for Lso by conventional PCR or produced tubers with ZC symptoms, whether fresh or fried. Results of these studies support findings by Henne et al. (2010c) and indicate that ZC-infected tubers seriously affect potato seed 
quality as the tubers do not sprout and if they do, produce hair sprouts and weak plants. However, Munyaneza et al. (2011b) concluded that the risk of spreading ZC through $Z C$-infected tubers was extremely low and not significant since the number of $\mathrm{ZC}$-infected tubers giving rise to infected was negligible and these plants are short-lived.

Very recently, Hamm (2012) reported a significant number of ZC-infected potato volunteers being observed in Columbia Basin of Washington and Oregon corn and wheat fields, following heavy psyllid infestation and severe ZC infection in these fields in 2011 and a mild winter. Interestingly, ZC-tubers collected from the same fields generally failed to sprout or produce ZC-infected plants when planted in the greenhouse following several months in storage (Hamm, personal communication). The reasons behind this discrepancy in ZC infection between field and greenhouse conditions are not known and warrant investigation.

Contrary to reports in older literature describing psyllid yellows-affected tubers (Richards and Blood 1933; Pletsch 1947; Wallis 1955; Cranshaw 1993), tubers produced by plants with psyllid yellows symptoms (following exposure of the plants to heavy and extensive feeding by Lso-free psyllids) during Munyaneza et al. (2011b) study appeared not to affect seed germination, normal plant growth, and yield. Similar observations were made by Berry et al. (2011) who reported that exposure of growing potato plants to Lsofree psyllids at different densities and for different periods of time under controlled field conditions did not appear to have a major influence on potato yield. Collectively, these findings suggest that serious and sporadic psyllid damage outbreaks in potato fields that were reported in the past and attributed to what was believed as psyllid yellows disease were more likely associated with Lso and ZC.

Little is known on the risk of $\mathrm{ZC}$ developing in potato tubers while in storage. This is especially a major concern for potatoes produced in the Pacific Northwest of the United States, where majority of tubers go into storage following harvest, and where potato fields appear to be subjected to Lso infection late in the growing season because of the late psyllid migration into potato fields (Munyaneza et al. 2009a; Crosslin et al. 2012a,b). It has been determined that all plant growth stages of potato are susceptible to $\mathrm{ZC}$ infection (Munyaneza and Buchman, unpublished data) and that it takes about three weeks after Lso inoculation for ZC symptoms to develop in potato plants and tubers (Buchman et al. 2012). Plants exposed to Lso-infected psyllids less than three weeks before harvest usually produce tubers without ZC symptoms (Buchman et al. 2012). It is not known how extensively or how rapidly symptomless but infected tubers develop ZC symptoms in storage. However, results of preliminary trials conducted in 2010 and 2011 indicated that an average of 10-22\% and 46-66.4\%, respectively, of symptomless tubers harvested from potato (cv. Atlantic) plants exposed to Lso-infective psyllids two to three weeks before harvest developed ZC symptoms after two and three months in storage (at $10{ }^{\circ} \mathrm{C}$ ) (Munyaneza and Buchman, unpublished data). Similarly, Rashed et al. (2011) reported ZC symptom development in potato tubers of the chipping cultivar FL1867 after three months in storage (at $5{ }^{\circ} \mathrm{C}$ ). The tubers were symptomless at harvest; tubers had been harvested from plants that had been exposed to Lso-infected psyllids two weeks prior to harvest. Further studies to elucidate this issue of the risk of postharvest $\mathrm{ZC}$ development are underway.

\section{Disease and Vector Management}

\section{Potato Psyllid Monitoring and Sampling}

Currently, all management tactics for ZC are targeted against the potato psyllid. Monitoring the potato psyllid is essential to effective management of this insect pest. Early season detection and management of this insect is crucial to minimize psyllid reproduction in the field and spread of ZC throughout fields.

Yellow sticky or water-pan traps are commonly used to monitor movement of the potato psyllid in a given region but are not recommended for estimating population density of this insect within fields (Al-Jabar and Cranshaw 2007; Goolsby et al. 2007a,b; 2012; Cameron et al. 2009; Butler and Trumble 2012a; Martini et al. 2012). Little is known on the attractiveness of different colors other than yellow to potato psyllid (Al-Jabr 1999; Al-Jabar and Cranshaw 2007; Goolsby et al. 2007a; Cameron et al. 2009). Studies by AlJabar and Cranshaw (2007) and Henne et al. (2010a) compared standard yellow sticky traps to those with different colors and reported that neon-green traps captured more adult potato psyllids than standard yellow traps. Efforts to identify the sex pheromone of the potato psyllid are underway (Guédot et al. 2011) and could potentially lead to an improved monitoring system for this insect pest.

Adult populations in potato fields are best sampled using sweep nets or vacuum devices, but egg and nymphal sampling requires visual examination of foliage that may necessitate the use of a field hand lens (Cranshaw 1994; Goolsby et al. 2007a, 2012; Butler and Trumble 2012a). Martini et al. (2012) recently developed a novel method referred to as "the leaf washing method or LWM" to quickly extract and count potato psyllid nymphs from leaves in commercial potato fields. The sampling method consists of immersing infested leaves in cold water to remove any dust and sand, placing the leaves in $85{ }^{\circ} \mathrm{C}$ hot water for $5 \mathrm{~s}$, extracting psyllid nymphs from the heated water by passing it through a sampling unit composed of a funnel and fine meshorganza fabric, and finally counting psyllid nymphs 
adhering to the organza fabric using a microscope. With the LWM method, Martini et al. (2012) were able to quickly determine distribution of potato psyllid in different parts of the plant and showed that potato psyllid nymphs were most predominant in the middle portion of the potato canopy.

Studies of spatial and temporal distribution of the potato psyllid indicated that both psyllid populations are highest at field edges initially, but if not controlled will eventually spread throughout the crop (Henne et al. 2010b; Butler and Trumble 2012b); spatial distribution of ZC within fields appears to follow a similar pattern (Henne et al. 2012; Workneh et al. 2012). In addition, Butler and Trumble (2012b) demonstrated that psyllids were mostly distributed on the top and middle portions of the potato plant and on the underside of leaves. Butler and Trumble (2012b) also developed a binomial sequential sampling plan for the potato psyllid and determined that sample sizes ranging from 12 to 16 plants per sample were needed to reach a treatment decision based on action thresholds of $0.5,1$, and 5 psyllids per plant.

$\mathrm{ZC}$ incidence in a given region or field depends not only on the abundance of the potato psyllid, but also on the incidence of Lso in the psyllid populations (Goolsby et al. 2012). Therefore, applications of insecticides targeted against the potato psyllid should take into consideration the infectivity of the vector. Spatial and temporal monitoring of Lso infectivity in the potato psyllids could help predict whether populations of psyllids present in a given area pose a significant risk of producing $\mathrm{ZC}$, and therefore should be targeted vigorously for control. Estimating Lso infection rate in the insects is easily accomplished by testing individuals or groups of psyllids using a PCR assay (Crosslin et al. 2011b). A potato psyllid trapping network has been established in the United States over a large geographic region (Goolsby et al. 2011, 2012); collected potato psyllids are tested weekly (Crosslin et al. 2011a) and the information is disseminated to the potato industry on a weekly basis to help potato producers make informed pest management decisions.

\section{Chemical Control}

Potato psyllid is currently controlled primarily by insecticide applications (Goolsby et al. 2007b; Vega-Guttierrez et al. 2008; Berry et al. 2009; Gharalari et al. 2009; Bynum et al. 2010; Zens et al. 2010; Butler et al. 2011a, 2012; Butler and Trumble 2012a), but even with insecticides the psyllid is difficult to manage. Good coverage, especially with contact insecticides, is important because psyllids are generally found primarily on the underside of leaves (Nansen et al. 2010; Butler and Trumble 2012b). Different life stages of the psyllid require the use of specific insecticides, as it has been shown that chemicals which control adults do not necessarily kill nymphs or eggs (Goolsby et al. 2007b; Gharalari et al. 2009; Zens et al. 2010). Therefore, caution is necessary when selecting and applying insecticides, requiring that growers consider which life stages are present in the crop, and then timing insecticide applications accordingly. Insecticides commonly used to control the potato psyllid include acephate, metamidophos, thiacloprid, buprofezin, abamectin, cypermethrin, deltamethrin, lambda-cyhalothrin, esfenvalerate, spinosad, spirotetramat, imidacloprid, thiamethoxam, spiromesifen, dinotefuran, pyriproxyfen, and pymetrozine (Goolsby et al. 2007b; Berry et al. 2009; Gharalari et al. 2009; Bynum et al. 2010; Tucuch-Haas et al. 2010; Zens et al. 2010; Butler et al. 2011a, 2012; Butler and Trumble 2012a).

The psyllid transmits Lso to potato within a few hours of colonizing a potato plant (Buchman et al. 2011a, b; 2012), thus psyllid controls must begin immediately upon detection of the insect in fields. Until the mid-2000s, potato growers in the southwestern United States relied on pyrethroids and organophosphates to control psyllids, but these insecticides did not provide adequate control and many growers still incurred severe damage and losses due to ZC (Guenthner and Greenway 2010; Guenthner et al. 2011). Because the potato psyllid in the southwestern United States is found in fields throughout the potato growing season, many potato growers in this region now routinely apply a neonicotinoid systemic insecticide at planting, followed by applications of foliar insecticides at regular intervals (Zens et al. 2010; Guenthner et al. 2011). It has been estimated that costs associated with ZC control in Texas in 2010 and 2011 range from US $\$ 170$ to $\$ 590$ per acre for an average of six to 10 applications of insecticides (Guenthner and Greenway 2010; Guenthner et al. 2011); despite these applications, some growers have nonetheless reported losses of up to $75 \%$.

Growers in the Pacific Northwest of the United States also face a challenge because of the psyllid's mid-season (late-June to late-July) arrival into potato fields (Munyaneza et al. 2009a; Rondon et al. 2012). Psyllid controls begin at plant emergence in the southwest because the psyllid is present at plant emergence. In contrast, seasonal timing of psyllid arrival into Pacific Northwest potato fields cannot be predicted year-to-year. Thus, growers in the Pacific Northwest face a great deal of uncertainty about when to begin psyllid controls in mid-season and how effective insecticides applied during that time are, although because of the shorter season fewer insecticide applications may be needed. Insecticide recommendations for the Pacific Northwest potatoes are discussed by Schreiber et al. (2012), and a model for ZC treatment decisions for Columbia was developed for the Columbia Basin of Washington and Oregon by Harris (2012). In Mexico and some Central America countries, where the psyllid is present all year round, routine weekly applications of insecticides targeted against the potato psyllid are common (Vega-Guttierrez et al. 2008; Espinoza 2010; Galviz et al. 2010; Rubio-Covarrubias et al. 2011b). For 
all geographic regions, there is a concern that insecticideheavy programs could eventually lead to resistance. Psyllids have been shown to develop insecticide resistance due to their high fecundity and short generation times (McMullen and Jong 1971).

Even a single psyllid per plant can effectively transmit Lso to potato and cause ZC. Coupled with a short inoculation access period (Buchman et al. 2011a,b; 2012), this causes a substantial challenge for growers in controlling the potato psyllid and preventing ZC transmission. Just a few infective psyllids feeding on potato for a short period can result in substantial spread of the disease within a potato field or region (Henne et al. 2012). Thus, conventional pesticides may often have only limited effectiveness at controlling ZC, as they may not kill the psyllid quickly enough to prevent Lso transmission, despite their effectiveness at reducing the overall population of psyllids. The most valuable and effective strategies to manage zebra chip would likely be those that discourage vector feeding, such as the use of plants that are resistant to psyllid feeding or that are less preferred by the psyllid.

Some conventional and biorational pesticides, including plant and mineral oils and kaolin, have been shown to reduce potato psyllid feeding and oviposition (Gharalari et al. 2009; Yang et al. 2010b; Peng et al. 2011; Butler et al. 2011a, 2012) and could be useful tools in integrated pest management programs to manage $\mathrm{ZC}$ and its psyllid vector. Yang et al. (2010b) showed that the biopesticides SunSpray mineral oil, BugOil (a mixture of four plant essential oils), or Requiem (a plant extract of Chenopodium ambrosioides) had significant repellency to adult potato psyllids (77.2$95.4 \%$ ) and strongly deterred oviposition (up to $100 \%$ ). Similarly, Diaz-Montano and Trumble (2012) have shown that volatiles from dimethyl disulfide and several plant essential oils are effective in repelling the potato psyllid and could be incorporated in IPM programs to better control ZC.

RNA interference (RNAi) technology is rapidly gaining attention as a potential strategy to manage insect pests and plant pathogens (Price and Gatehouse 2008). Efforts to investigate whether RNAi can be used to control potato psyllid are underway. With the goal of developing an RNAi-based management strategy for $B$. cockerelli, Hail et al. (2010) used pyrosequencing technology to identify target genes and synthetic dsRNA. Constructs were designed to block the activity of heat shock protein 70 and heat shock cognate 70 , molecular chaperones that are intimately involved in essentially all life processes by folding and stabilizing other proteins in the potato psyllid. Hail et al. (2010) plan to target other genes and deliver RNAi to psyllids via the plant through a root soaking procedure. Wuriyanghan et al. (2011) recently demonstrated the induction of specific RNAi effects in $B$. cockerelli by injection and oral acquisition of dsRNA and siRNA inducers that targeted ubiquitously expressed and gut-abundant mRNAs, resulting in significant mortality of the psyllid. Results of this study support the possibility of potentially using RNAi-based strategies to control the potato psyllid for ZC management. Another novel strategy currently being explored to manage $\mathrm{ZC}$ is the use of antibiotics and metal phosphites. Results of a recent trial using foliar applications of selected antibiotics to potato plants in southern Texas by Henne et al. (2011) indicated that these products can be used to effectively remediate $\mathrm{ZC}$-infected plants and/or prevent the onset of $\mathrm{ZC}$ symptoms.

\section{Biological Control}

Potato psyllid is attacked by a number of natural enemies, including chrysopid larvae, coccinellids, geocorids, anthocorids, mirids, nabids, syrphid larvae, and the parasitoids Tamarixia triozae (Hymenoptera: Eulophidae) and Metaphycus psyllidis (Hymenoptera: Encyrtidae) but little is known about their effects on psyllid populations (Pletsch 1947; Wallis 1955; Cranshaw 1993; Al-Jabr 1999; Butler et al. 2010; Butler and Trumble 2012a; Liu et al. 2012). In addition, several entomopathogenic fungi, including Beauveria bassiana, Metarhizium anisopliae, and Isaria fumosorosae, have been determined to be effective natural enemies of $B$. cockerelli, causing psyllid mortality up to 99 and $78 \%$ under laboratory and field conditions, respectively (Lacey et al. 2009, 2011).

\section{Cultural Control}

Little is known about what cultural practices could help mitigate damage caused to potato crops by ZC. Studies by Munyaneza et al. (2010a) and Trevino et al. (2011) indicated that in some areas of the Lower Rio Grande Valley of southern Texas, early (December-January) planted potato crops are more susceptible to psyllid injury and ZC than crops planted mid-season or later (February-March). This trend was not observed for potato fields located north of the Lower Rio Grande Valley (Trevino et al. 2011). The reasons behind the differences in ZC incidence based on planting timing between the two regions are not known. However, it is suspected that differences in ZC incidence between the two potato growing regions of Texas may have been due to yearly and seasonal fluctuations in Lso infection rate in overwintering and migrating psyllids. The potato psyllid is believed to overwinter along the Rio Grande River between Texas and Mexico and migrates northward with increasing high temperatures (Pletsch 1947; Wallis 1955). It is possible that overwintered potato psyllids in early-planted potatoes in the Lower Rio Grande Valley of Texas were more infected with the bacterium than psyllids attacking potatoes in more northern regions (Munyaneza et al. 2010a). Further studies are 
needed to elucidate the impact of planting timing on $\mathrm{ZC}$ incidence in potato crops.

\section{Plant Host Resistance}

Development and identification of potato varieties and/or advanced breeding lines with resistance to or tolerance of $\mathrm{ZC}$, using traditional breeding methods or genetic engineering, are crucial to development of effective and sustainable management strategies for this emerging and important potato disease. Unfortunately, it has been shown that most, if not all, commercial potato varieties currently available in the United States and elsewhere are susceptible to ZC (Munyaneza et al. 2011d), underscoring the urgent need to identify and/or develop potatoes that are resistant to this important disease. Efforts to develop resistant cultivars and screening trials to identify potato varieties and advanced breeding lines with resistance to $\mathrm{ZC}$ and the potato psyllid are currently underway (Butler et al. 2010, 2011b; Miller et al. 2010; Munyaneza et al. 2010b; Novy et al. 2010; Pierson et al. 2010; Munyaneza et al. 2011a; Rubio-Covarrubias et al. 2011b; Butler and Trumble 2012a). Preliminary results suggest that some advanced potato breeding lines are promising and may be resistant to or tolerant of $\mathrm{ZC}$ and/or the potato psyllid and warrant further evaluation (Munyaneza et al. 2011a; Rubio-Covarrubias et al. 2011b). Furthermore, development of genetically modified potato material to manage the potato psyllid and ZC is being explored. Curtis et al. (2010) demonstrated that there was a delay in the onset of ZC symptoms into transgenic potato plants that were generated through Agrobacterium-mediated transformation carrying either plant derived antimicrobial or anti-insect genes after being exposed to Lso-infected psyllids; a reduction of the level of bacterial inoculum in plant tissues was also observed.

\section{Conclusion}

$\mathrm{ZC}$ is an emerging and economically important disease of potato in several parts of the world. It is imperative that management strategies be developed to effectively manage the disease. ZC is associated with Lso which is transmitted to potato by the potato psyllid. Thus, increasing the understanding of both the disease causal agent and its insect vector is essential. In this literature review paper, ZC history and geographic distribution, biology, epidemiology, and management were extensively discussed. Particularly, pertinent and available information on the disease causal bacterium and its insect vector was provided. This information will help potato producers, processors, and researchers to develop management strategies for both Lso and $B$. cockerelli in order to minimize damage caused to potato by this devastating disease.

Acknowledgments I am grateful to anonymous reviewers who made suggestions to improve an earlier version of this paper. Financial support for this work was partially provided by Frito Lay, Inc., USDAARS State Partnership Potato Research Program, Texas Department of Agriculture, USDA-RAMP (Project \# 2009-51101-05892) and USDASCRI (Project \#2009-51181-20176). The use of trade, firm, or corporation names in this publication is for information and convenience of the reader. Such use does not constitute an official endorsement or approval by the United States Department of Agriculture or the Agricultural Research Service of any product or service to the exclusion of others that may be suitable. USDA is an equal opportunity provider and employer.

\section{References}

Abad, J.A., M. Bandla, R.D. French-Monar, L.W. Liefting, and G.R.G. Clover. 2009. First report of the detection of 'Candidatus Liberibacter' species in zebra chip disease-infected potato plants in the United States. Plant Disease 93: 108.

Abdullah, N.M.M. 2008. Life history of the potato psyllid Bactericera cockerelli (Homoptera: Psyllidae) in controlled environment agriculture in Arizona. African Journal of Agricultural Research 3: 60-67.

Abernathy, R.L. 1991. Investigation into the nature of the potato psyllid toxin. M.S. Thesis, Colorado State University, Fort Collins, CO.

Alfaro-Fernández, A., M.C. Cebrián, F.J. Villaescusa, A. Hermoso de Mendoza, J.C. Ferrándiz, S. Sanjuán, and M.I. Font. 2012a. First report of 'Candidatus Liberibacter solanacearum' in carrot in mainland Spain. Plant Disease 96: 582.

Alfaro-Fernández, A., F. Siverio, M.C. Cebrián, F.J. Villaescusa, and M.I. Font. 2012b. 'Candidatus Liberibacter solanacearum' associated with Bactericera trigonica-affected carrots in the Canary Islands. Plant Disease 96: 581.

Al-Jabar, A.M., and W.S. Cranshaw. 2007. Trapping tomato psyllid, Bactericera cockerelli (Sulc) (Hemiptera: Psyllidae), in greenhouses. Southwestern Entomologist 32: 25-30.

Al-Jabr, A.M. 1999. Integrated pest management of tomato/potato psyllid, Paratrioza cockerelli (Sulc) (Homoptera: Psyllidae) with emphasis on its importance in greenhouse grown tomatoes. Ph.D. Dissertation, Colorado State University, Fort Collins, CO.

Alvarado, V.Y., D. Odokonyero, O. Duncan, T.E. Mirkov, and H.B. Scholthof. 2012. Molecular and physiological properties associated with zebra chip complex disease in potatoes and its relation with Candidatus Liberibacter contents in psyllid vectors. PloS One 7(5): e37345. doi:10.1371/journal.pone.0037345.

Arslan, A., P.M. Bessey, K. Matasuda, and N.F. Oebker. 1985. Physiological effects of psyllid (Paratrioza cockerelli) on potato. American Journal of Potato Research 62: 9-22.

Berry, N.A., M.K. Walker, and R.C. Butler. 2009. Laboratory studies to determine the efficacy of selected insecticides on tomato/potato psyllid. New Zealand Plant Protection 62: 145-151.

Berry, N., S. Thompson, N. Taylor, P. Wright, F. Shah, M. Walker, S. Beard, N. Jorgensen, R. Butler, S. Thompson, I. Scott, and A.R. Pitman. 2011. The impact of $C a$. Liberibacter infected seed tubers on potato production in New Zealand, pp. 178-182. In Proceedings of the 11 th Annual Zebra Chip Reporting Session, ed. F. Workneh, A Rashed, and C.M. Rush. Dallas, TX (November 6-9, 2011).

Binkley, A.M. 1929. Transmission studies with the new psyllid yellows disease of solanaceous plants. Science 70: 615.

Bové, J.M. 2006. Huanglongbing: a destructive, newly-emerging, century-old disease of citrus. Journal of Plant Pathology 88: 7-37.

Brown, J.K., M. Rehman, D. Rogan, R.R. Martin, and A.M. Idris. 2010. First report of "Candidatus Liberibacter psylaurous" (syn. "Ca. L. solanacearum") associated with the "tomato veingreening' and 'tomato psyllid yellows' diseases in commercial greenhouse in Arizona. Plant Disease 94: 376.

Buchman, J.L., B.E. Heilman, and J.E. Munyaneza. 2011a. Effects of Bactericera cockerelli (Hemiptera: Triozidae) density on zebra 
chip potato disease incidence, potato yield, and tuber processing quality. Journal of Economic Entomology 104: 1783-1792.

Buchman, J.L., V.G. Sengoda, and J.E. Munyaneza. 2011b. Vector transmission efficiency of liberibacter by Bactericera cockerelli (Hemiptera: Triozidae) in zebra chip potato disease: effects of psyllid life stage and inoculation access period. Journal of Economic Entomology 104: 1486-1495.

Buchman, J.L., T.W. Fisher, V.G. Sengoda, and J.E. Munyaneza. 2012. Zebra chip progression: from inoculation of potato plants with liberibacter to development of disease symptoms in tubers. American Journal of Potato Research 89: 159-168.

Butler, C.D., and J.T. Trumble. 2012a. The potato psyllid, Bactericera cockerelli (Sulc) (Hemiptera: Triozidae): life history, relationship to plant diseases, and management strategies. Terrestrial Arthropod Reviews 5: 87-111.

Butler, C.D., and J.T. Trumble. 2012b. Spatial dispersion and binomial sequential sampling for the potato psyllid (Hemiptera: Triozidae) on potato. Pest Management Science 68: 865-869.

Butler, C.D., R.G. Novy, J.C. Miller, and J.T. Trumble. 2010. Alternative strategies: plant resistance and biological control, pp. 69-73. In Proceedings of the 10th Annual Zebra Chip Reporting Session, ed. F. Workneh and C.M. Rush. Dallas, TX (November 7-10, 2010).

Butler, C.D., F.R. Byrne, M.L. Keremane, R.F. Lee, and J.T. Trumble. 2011a. Effects of insecticides on behavior of adult Bactericera cockerelli (Hemiptera: Triozidae) and transmission of Candidatus Liberibacter psyllaurous. Journal of Economic Entomology 104: 586-594.

Butler, C.D., B. Gonzalez, K.L. Manjunath, R.E. Lee, R.G. Novy, J.C. Miller, and J.T. Trumble. 2011b. Behavioral responses of adult potato psyllid, Bactericera cockerelli (Hemiptera: Triozidae), to potato germplasm and transmission of Candidatus Liberibacter psyllaurous. Crop Protection 30: 1233-1238.

Butler, C.D., G.P. Walker, and J.T. Trumble. 2012. Feeding disruption of potato psyllid, Bactericera cokerelli, by imidacloprid as measured by electrical penetration graphs. Entomologia Experimentalis et Applicata 142: 247-257.

Bynum, E., D.C. Henne, andC.M. Rush. 2010. Evaluation of spray applications for potato psyllid and ZC management, pp. 88-92. In Proceedings of the 10th Annual Zebra Chip Reporting Session, ed. F. Workneh and C.M. Rush. Dallas, TX (November 7-10, 2010).

Cameron, P.J., M.R. Surrey, P.J. Wigley, J.A.D. Anderson, D.E. Hartnett, and A.R. Wallace. 2009. Seasonality of Bactericera cockerelli in potatoes (Solanum tubersom) in South Auckland, New Zealand. New Zealand Journal of Crop and Horticultural Science 37: 295-301.

Capinera, J.L. 2001. Handbook of vegetable pests. San Diego: Academic

Casteel, C.L., A.K. Hansen, L.L. Walling, and T.D. Paine. 2012. Manipulation of plant defense responses by the tomato psyllid (Bactericera cockerelli) and its associated endosymbiont Candidatus Liberibacter psyllaurous. PloS One 7(4): e35191. doi:10.1371/journal.pone.0035191.

Cebrián, M.C., F.J. Villaescusa, A. Alfaro-Fernández, A. Hermoso de Mendoza, M.C. Cárdoba-Selleés, C. Jorda, J.C. Ferrándiz, S. Sanjuan, and M.I. Font. 2010. First report of Spiroplasma citri in carrot in Europe. Plant Disease 94: 1264.

Cicero, J.M., J.K. Brown, P.D. Roberts, and P.A. Stansly. 2009. The digestive system of Diaphorina citri and Bactericera cockerelli (Hemiptera: Psyllidae). Annals of the Entomological Society of America 102: 650-665.

CNAS. 2006. Economic impacts of zebra chip on the Texas potato industry. Center for North American Studies, http://cnas.tamu.edu/ zebra\%20chip\%20impacts\%20final.pdf.

Compere, H. 1915. Paratrioza cockerelli (Sulc). Monthly Bulletin of California State Commission of Horticulture 4: 574.

Compere, H. 1916. Notes on the tomato psylla. Monthly Bulletin of California State Commission of Horticulture 5: 189-191.
Costa Rica-MAG. 2012. Costa Rica toma medidas ante presencia de plaga en frontera norte. Comunicado de Prensa CP-07-2012.

Cranshaw, W.S. 1993. An annotated bibliography of potato/tomato psyllid, Paratrioza cockerelli (Sulc) (Homptera; Psyllidae). Colorado State University Agricultural Experiment Station Bulletin TB93-5.

Cranshaw, W.S. 1994. The potato (tomato) psyllid, Paratrioza cockerelli (Sulc), as a pest of potatoes. In Advances in potato pest biology and management, ed. G.W. Zehnder, M.L. Powelson, R.K. Hansson, and K.V. Raman, 83-95. St. Paul, MN: APS Press.

Cranshaw, W.S. 2001. Diseases caused by insect toxin: psyllid yellows, pp. 73-74. In Compendium of Potato Diseases (2nd Ed.), ed. W.R. Stevenson, R. Loria, G.D. Franc, and D.P. Weingartner. APS Press, St. Paul, MN.

Crosslin, J.M., and G. Bester. 2009. First report of Candidatus Liberibacter psyllaurous in zebra chip symptomatic potatoes from California. Plant Disease 93: 551.

Crosslin, J.M., and J.E. Munyaneza. 2009. Evidence that the zebra chip disease and the putative causal agent can be maintained in potatoes by grafting and in vitro. American Journal of Potato Research 86: $183-187$.

Crosslin, J.M., J.E. Munyaneza, A.S. Jensen, and P.B. Hamm. 2005. Association of the beet leafhopper (Hemiptera: Cicadellidae) with a clover proliferation group phytoplasma in the Columbia Basin of Washington and Oregon. Journal of Economic Entomology 98: 279-283.

Crosslin, J.M., J.E. Munyaneza, J.K. Brown, and L.W. Liefting. 2010. Potato zebra chip disease: a phytopathological tale. Online. Plant Health Progress. doi:10.1094/PHP-2010-0317-01-RV.

Crosslin, J.M., J.A. Goolsby, and J.E. Munyaneza. 2011a. Liberibacter testing of 2011 psyllids and research update, pp. 17-21. In Proceedings of the 11th Annual Zebra Chip Reporting Session, ed. F. Workneh, A. Rashed, and C.M. Rush. San Antonio, TX (November 6-9, 2011).

Crosslin, J.M., H. Lin, and J.E. Munyaneza. 2011b. Detection of 'Candidatus Liberibacter solanacearum' in the potato psyllid, Bactericera cockerelli (Sulc), by conventional and real-time PCR. Southwestern Entomologist 36: 125-135.

Crosslin, J.M., P.B. Hamm, J.E. Eggers, S.I. Rondon, V.G. Sengoda, and J.E. Munyaneza. 2012a. First report of zebra chip disease and "Candidatus Liberibacter solanacearum" on potatoes in Oregon and Washington State. Plant Disease 96: 452.

Crosslin, J.M., N. Olsen, and P. Nolte. 2012b. First report of zebra chip disease and "Candidatus Liberibacter solanacearum" on potatoes in Idaho. Plant Disease 96: 453.

Curtis, L.S., P. Tantravahi, and T.E. Mirkov. 2010. An evaluation of plant-derived antimicrobial and anti-insect genes on reducing zebra chip disease in transgenic potato, pp. 110-114. In Proceedings of the 10th Annual Zebra Chip Reporting Session, ed. F. Workneh, and C.M. Rush. Dallas, TX (November 7-10, 2010).

Daniels, L.B. 1954.The nature of the toxicogenic condition resulting from the feeding of the tomato psyllid Paratrioza cockerelli (Sulc). Ph.D. Dissertation, University of Minnesota.

Diaz-Montano J., and J.T. Trumble. 2012. Behavioral responses of the potato psyllid (Hemiptera: Triozidae) to volatiles from Dimethyl Disulfide and plant essential oils. Journal of Insect Behavior. doi:10.1007/s10905-012-9350-8.

Ember, I., Z. Acs, J.E. Munyaneza, J.M. Crosslin, and M. Kolber. 2011. Survey and molecular detection of phytoplasmas associated with potato in Romania and Southern Russia. European Journal of Plant Pathology 130: 367-377.

EPPO. 2012. First report of 'Candidatus Liberibacter solanacearum' on carrots and celery in Spain, in association with Bactericera trigonica. EPPO Reporting Service - Pests and Diseases 6: 4-5.

Espinoza, H.R. 2010. Facing the Bactericera cockerelli/Candidatus Liberibacter complex in Honduras, pp. 47-49. In Proceedings of 
the 10th Annual Zebra Chip Reporting Session, ed. F. Workneh, and C.M. Rush. Dallas, TX (November 7-10, 2010).

Essig, E.O. 1917. The tomato and laurel psyllids. Journal of Economic Entomology 10: 433-444.

Eyer, J.R. 1937. Physiology of psyllid yellows of potatoes. Journal of Economic Entomology 30: 891-898.

Eyer, J.R., and R.F. Crawford. 1933. Observations on the feeding habits of the potato psyllid (Paratrioza cockerelli Sulc.) and the pathological history of the "psyllid yellows" which it produces. Journal of Economic Entomology 26: 846-850.

Ferguson, G., and L. Shipp. 2002. New pests in Ontario greenhouse vegetables. Working Group "International Control in Protected Crops, Temperate Climate". Bulletin of the International Organization for Biological Control of Noxious Animals and Plants. West Palearctic Regional Section 25: 69-72.

Font, I., P. Abad, M. Albiñana, A.I. Espino, E.L. Dally, R. Davis, and C. Jorda. 1999. Amarilleos y anrojecimientos en zanahoria: una enfermedad a diagnóstico. Boletín de Sanidad Vegetal 25: 405-415.

French-Monar, R.D., F. Patto, J.M. Douglas, J.A. Abad, G. Schuster, W. Wallace, and T.A. Wheeler. 2010. First report of "Candidatus Liberibacter solanacearum" on field tomatoes in the United States. Plant Disease 94: 481.

Galviz, R., V. Hernandez, A. Sanchez, M. Barrera, G. Frias, and F. Durazo. 2010. Highlights on zebra chip Mexican experiences, pp. 42-46. In Proceedings of the 10th Annual Zebra Chip Reporting Session, ed. F. Workneh and C.M. Rush. Dallas, TX (November 7-10, 2010).

Gao, F., J. Jifon, X. Yang, and T.-X. Liu. 2009. Zebra chip disease incidence on potato is influenced by timing of potato psyllid infestation, but not by the host plants on which they were reared. Insect Science 16: 399-408.

Gharalari, A.H., C. Nansen, D.S. Lawson, J. Gilley, J.E. Munyaneza, and K. Vaughn. 2009. Knockdown mortality, repellency, and residual effects of insecticides for control of adult Bactericera cockerelli (Hemiptera: Psyllidae). Journal of Economic Entomology 102: 1032-1038.

Gill, G. 2006. Tomato psyllid detected in New Zealand. Biosecurity New Zealand 69: 10-11.

Goolsby, J.A., B. Bextine, J.E. Munyaneza, M. Sétamou, J. Adamczyk, and G. Bester. 2007a. Seasonal abundance of sharpshooters, leafhoppers, and psyllids associated with potatoes affected by zebra chip disorder. Subtropical Plant Science 59: 15-23.

Goolsby, J.A., J. Adamczyk, B. Bextine, D. Lin, J.E. Munyaneza, and G. Bester. 2007b. Development of an IPM program for management of the potato psyllid to reduce incidence of zebra chip disorder in potatoes. Subtropical Plant Science 59: 85-94.

Goolsby, J.A., J.J. Adamczyk, J.M. Crosslin, N.N. Troxclair, J.R. Anciso, G.G. Bester, J.D. Bradshaw, E.D. Bynum, L.A. Carpio, D.C. Henne, A. Joshi, J.E. Munyaneza, P. Porter, P.E. Sloderbeck, J.R. Supak, C.M. Rush, F.J. Willett, B.J. Zechmann, and B.A. Zens. 2011. Regional monitoring of potato psyllid populations and the associated pathogen, $\mathrm{Ca}$. Liberibacter psyllaurous, pp. 12-16. In Proceedings of the 11th Annual Zebra Chip Reporting Session, ed. F. Workneh, A. Rashed, and C.M. Rush. San Antonio, TX (November 6-9, 2011).

Goolsby, J.A., J.J. Adamczyk, J.M. Crosslin, N.N. Troxclair, J.R. Anciso, G.G. Bester, J.D. Bradshaw, E.D. Bynum, L.A. Carpio, D.C. Henne, A. Joshi, J.E. Munyaneza, P. Porter, P.E. Sloderbeck, J.R. Supak, C.M. Rush, F.J. Willett, B.J. Zechmann, and B.A. Zens. 2012. Seasonal population dynamics of the potato psyllid (Hemiptera: Triozidae) and its associated pathogen "Candidatus Liberibacter solanacearum" in potatoes in the southern Great Plains of North America. Journal of Economic Entomology 105: 1268-1278.

Gudmestad, N.C., and G.A. Secor. 2007. Zebra chip: a new disease of potato. Potato Eyes 19: 1-4.
Guédot, C., D.R. Horton, and P.J. Landolt. 2010. Sex attraction in the potato psyllid Bactericera cockerelli (Hemiptera: Triozidae). Environmental Entomology 39: 1302-1308.

Guédot C., D.R. Horton, P.J. Landolt, J.E. Munyaneza, and J. Millar. 2011. Efforts to identify the sex pheromone of the potato psyllid, pp. 112-116. In Proceedings of the 11th Annual Zebra Chip Reporting Session, ed. F. Workneh, A. Rashed, and C.M. Rush. San Antonio, TX (November 6-9, 2011).

Guédot, C., D.R. Horton, and P.J. Landolt. 2012. Age at reproductive maturity and effect of age and time of day on sex attraction in the potato psyllid Bactericera cockerelli. Insect Science. doi:10.1111/ j.1744-7917.2011.01498.x.

Guenthner, J., and G. Greenway. 2010. Zebra chip economics, pp. 93-95.In Proceedings of the 10th Annual Zebra Chip Reporting Session, ed. F. Workneh, and C.M. Rush. Dallas, TX (November 7-10, 2010).

Guenthner, J., G. Greenway, and J. Goolsby. 2011. Zebra chip economics, pp. 168-172. In Proceedings of the 11th Annual Zebra Chip Reporting Session, ed. F. Workneh, A. Rashed, and C.M. Rush. San Antonio, TX (November 6-9, 2011).

Hail, D.A., S. Dowd, W.H. Hunter, and B. Bextine. 2010. Investigating the transcriptome of the potato psyllid (Bactericera cockerelli): toward an RNAi based management strategy, pp. 183-186. In Proceedings of the 10th Annual Zebra Chip Reporting Session, ed. F. Workneh and C.M. Rush. Dallas, TX (November 7-10, 2010).

Hail, D., S.E. Dowd, and B. Bextine. 2012. Identification and location of symbionts associated with potato psyllid (Bactericera cockerelli) life stages. Environmental Entomology 41: 98-107.

Halbert, S.E., and J.E. Munyaneza. 2012. Potato psyllids and associated pathogens: a diagnostic aid. Florida State Collection of Arthropods, Gainesville, FL. Online: http://www.fsca-dpi.org/Homoptera Hemiptera/Potato_psyllids_and_associated_pathogens.pdf

Hamm, P. 2012. Zebra chip found in volunteers. Potato Progress 12 (11): 1-2.

Hamm, P.B., S.I. Rondon, J.M. Crosslin, and J.E. Munyaneza. 2011. A new threat in the Columbia Basin of Oregon and Washington: zebra chip, pp. 1-5. In Proceedings of the 11th Annual Zebra Chip Reporting Session, ed. F. Workneh, A. Rashed, and C.M. Rush. San Antonio, TX (November 6-9, 2011).

Hansen, A.K., J.T. Trumble, R. Stouthamer, and T.D. Paine. 2008. A new huanglongbing species, 'Candidatus Liberibacter psyllaurous' found to infect tomato and potato, is vectored by the psyllid Bactericera cockerelli (Sulc). Applied and Environmental Microbiology 74: $5862-5865$.

Harris, B. 2012. Analysis of the zebra chip treatment decision facing potato farmers in the Columbia Basin. M.S. Thesis, University of Idaho, Moscow, ID.

Henne, D.C., L. Paetzold, F. Workneh, and C.M. Rush. 2010a. Evaluation of potato psyllid cold tolerance, overwintering survival, sticky trap sampling, and effects of liberibacter on potato psyllid alternate host plants, pp.149-153. In Proceedings of the 10th Annual Zebra Chip Reporting Session, ed. F. Workneh and C.M. Rush. Dallas, TX (November 7-10, 2010).

Henne, D.C., F. Workneh, and C.M. Rush. 2010b. Movement of Bactericera cockerelli (Heteroptera: Psyllidae) in relation to potato canopy structure, and effects of potato tuber weights. Journal of Economic Entomology 103: 1524-1530.

Henne, D.C., F. Workneh, A. Wen, A.A. Price, J.S. Pasche, N.C. Gudmestad, and C.M. Rush. 2010c. Characterization and epidemiological significance of potato plants grown from seed tubers affected by zebra chip disease. Plant Disease 94: 659-665.

Henne, D.C., J.A. Goolsby, T.E. Mirkov, and J.E. Munyaneza. 2011. Potato psyllid and zebra chip disease management in South Texas, pp. 41-45. In Proceedings of the 11th Annual Zebra Chip Reporting Session, ed. F. Workneh, A. Rashed, and C.M. Rush. San Antonio, TX (November 6-9, 2011). 
Henne, D.C., F. Workneh, and C.M. Rush. 2012. Spatial patterns and spread of potato zebra chip disease in the Texas Panhandle. Plant Disease 96: 948-956.

Jackson, B.C., J. Goolsby, A. Wyzykowski, N. Vitovksy, and B. Bextine. 2009. Analysis of genetic relationship between potato psyllid (Bactericera cokerelli) populations in the United States, Mexico, and Guatemala using ITS2 and inter simple sequence repeat (ISSR) data. Subtropical Plant Science 61: 1-5.

Jagoueix, S., J.M. Bove, and M. Garnier. 1994. PCR detection of the two 'Candidatus' Liberobacter species associated with greening disease of citrus. Molecular and Cellular Probes 10: 43-50.

Jensen, D.D. 1954. Notes on the potato psyllid, Paratrioza cockerelli (Sulc) (Hemiptera: Psyllidae). Pan-Pacific Entomologist 30: 161-165.

Jensen, A. 2012. Updates on potato psyllid and zebra chip (ZC). Potato Progress 12(10): 1-6.

Knowlton, G.F., and M.J. Janes. 1931. Studies on the biology of Paratrioza cockerelli (Sulc). Annals of the Entomological Society of America 24: 283-291.

Knowlton, G.F., and W.L. Thomas. 1934. Host plants of the potato psyllid. Journal of Economic Entomology 27: 547.

Kölber, M., Z. Acs, I. Ember, Z. Nagy, C. Talaber, J. Horrocks, I. Hope-Johnstone, S. Marchenko, V. Gonchar, I. Kiselev, A. Lupascu, M. Munteanu, and N. Filip. 2010. Phytoplasma infection of chips potatoes in Romania and South Russia (2008-2010), pp. 50-54. In Proceedings of the 10th Annual Zebra Chip reporting Session, ed. F. Workneh and C.M. Rush. Dallas, TX (November 7-10, 2010).

Lacey, L.A., F. de la Roza, and D.R. Horton. 2009. Insecticidal activity of entomopathogenic fungi (Hypocreales) for potato psyllid, Bactericera cockerelli (Hemiptera: Triozidae): development of bioassay techniques, effect of fungal species and stage of the psyllid. Biocontrol Science and Technology 19: 957-970.

Lacey, L.A., T.-X. Liu, J.L. Buchman, J.E. Munyaneza, J.A. Goolsby, and D.R. Horton. 2011. Entomopathogenic fungi (Hypocreales) for control of potato psyllid, Bactericera cockerelli (Šulc) (Hemiptera: Triozidae) in an area endemic for zebra chip disease of potato. Biological Control 56: 271-278.

Lee, I.M., K.D. Bottner, J.E. Munyaneza, R.E. Davis, J.M. Crosslin, L.J. du Toit, and T. Crosby. 2006. Carrot purple leaf: a new spiroplasmal disease associated with carrots in Washington State. Plant Disease 90: 989-993.

Levy, J., A. Ravindran, D. Gross, C. Tamborindeguy, and E. Pierson. 2011. Translocation of 'Candidatus Liberibacter solanacearum', the zebra chip pathogen, in potato and tomato. Phytopathology 101: $1285-1291$

Li, W., J.A. Abad, R.D. French-Monar, J. Rascoe, A. Wen, N.C. Gudmestad, G.A. Secor, I.M. Lee, Y. Duan, and L. Levy. 2009. Multiplex real-time PCR for detection, identification and quantification of 'Candidatus Liberibacter solanacearum' in potato plants with zebra chip. Journal of Microbiological Methods 78: 59-65.

Liefting, L.W., Z.C. Perez-Egusquiza, G.R.G. Clover, and J.A.D. Anderson. 2008a. A new 'Candidatus Liberibacter' species in Solanum tuberosum in New Zealand. Plant Disease 92: 1474.

Liefting, L.W., L.I. Ward, J.B. Shiller, and G.R.G. Clover. 2008b. A new 'Candidatus Liberibacter' species in Solanum betaceum (tamarillo) and Physalis peruviana (cape gooseberry) in New Zealand. Plant Disease 92: 1588 .

Liefting, L.W., P.W. Sutherland, L.I. Ward, K.L. Paice, B.S. Weir, and G.R.G. Clover. 2009a. A new 'Candidatus Liberibacter' species associated with diseases of solanaceous crops. Plant Disease 93: 208-214.

Liefting, L.W., S. Veerakone, L.I. Ward, and G.R.G. Clover. 2009b. First report of 'Candidatus Phytoplasma australiense' in potato. Plant Disease 93: 969.

Liefting, L.W., B.S. Weir, S.R. Pennycook, and G.R.G. Clover. 2009c. 'Candidatus Liberibacter solanacearum', associated with plants in the family Solanaceae. International Journal of Systematics and Evolutionary Microbiology 59: 2274-2276.

Lin, H., H. Doddapaneni, J.E. Munyaneza, E. Civerolo, V.G. Sengoda, J.L. Buchman, and D.C. Stenger. 2009. Molecular characterization and phylogenetic analysis of 16S rRNA from a new species of "Candidatus Liberibacter" associated with zebra chip disease of potato (Solanum tuberosum L.) and the potato psyllid (Bactericera cockerelli Sulc). Journal of Plant Pathology 91: 215-219.

Lin, H., J. Glynn, M.S. Islam, A. Wen, and N.C. Gudmestad. 2011a. Multilocus sequencing typing markers for genotyping and population genetic analyses of Candidatus Liberibacter solanacearum, pp. 32 35. In Proceedings of the 11th Annual Zebra Chip Reporting Session, ed. F. Workneh, A. Rashed, and C.M. Rush. San Antonio, TX (November 6-9, 2011).

Lin, H., B. Lou, J.M. Glynn, H. Doddapaneni, E. Civerolo, C. Chen, Y. Duan, L. Zhou, and C.M. Vahling. 2011b. The complete genome sequence of 'Candidatus Liberibacter solanacearum', the bacterium associated with potato zebra chip disease. PloS One 6: e19135. doi:10.1371/journal.pone.0019135.

Lin, H., M.S. Islam, Y. Bai, A. Wen, S. Lan, N.C. Gudmestad, and E.L. Civerolo. 2012. Genetic diversity of 'Candidatus Liberibacter solanacearum' strains in the United States and Mexico revealed by simple sequence repeat markers. European Journal of Plant Pathology 132: 297-308.

List, G.M. 1939. The effect of temperature upon egg deposition, egg hatch and nymphal development of Paratrioza cockerelli (Sulc). Journal of Economic Entomology 32: 30-36.

List, G.M., and L.B. Daniels. 1934. A promising control for psyllid yellows of potatoes. Science 79: 79 .

Liu, D., and J.T. Trumble. 2007. Comparative fitness of invasive and native populations of the potato psyllid (Bactericera cockerelli). Entomologia Experimentalis et Applicata 123: 35-42.

Liu, D., J.T. Trumble, and R. Stouthamer. 2006. Genetic differentiation between eastern populations and recent introductions of potato psyllid (Bactericera cockerelli) into western North America. Entomologia Experimentalis et Applicata 118: 177-183.

Liu, T.X., Y.M. Zhang, L.N. Peng, P. Rojas, and J.T. Trumble. 2012. Risk assessment of selected insecticides on Tamarixia triozae (Hymenoptera: Eulophidae), a parasitoid of Bactericera cockerelli (Hemiptera: Triozodae). Journal of Economic Entomology 105: 490-496.

Martini, X., S. Seibert, S.M. Prager, and C. Nansen. 2012. Sampling and interpretation of psyllid nymph counts in potatoes. Entomologia Experimentalis et Applicata 143: 103-110.

McKenzie, C.L., and R.G. Shatters Jr. 2009. First report of "Candidatus Liberibacter psyllaurous" associated with psyllid yellows of tomato in Colorado. Plant Disease 93: 1074.

McMullen, R.D., and C. Jong. 1971. Dithiocarbamate fungicides for control of pear psylla. Journal of Economic Entomology 64: $1266-1270$.

Miles, G.P., J.L. Buchman, and J.E. Munyaneza. 2009. Impact of Zebra Chip Disease on the Mineral Content of Potato Tubers. American Journal of Potato Research 86: 481-489.

Miles, G.P., M.A. Samuel, J. Chen, E.L. Civerolo, and J.E. Munyaneza. 2010. Evidence that cell death is associated with zebra chip disease in potato tubers. American Journal of Potato Research 87: 337-349.

Miller, J.C., D.C. Scheuring, J. Koym, S.D. Turner, R.G. Novy, J.T. Trumble, C.D. Butler, C. Nansen, K. Vaughn, T.X. Liu, J.E. Munyaneza, E. Pierson, C.M. Rush, J. Jifon, R. French, C. Tamborindeguy, and P. Porter. 2010. Progress in identifying host plant tolerance/resistance to $\mathrm{ZC}$ in potato germplasm, pp. 96-98. In Proceedings of the 10th Annual Zebra Chip Reporting Session, ed. F. Workneh and C.M. Rush. Dallas, TX (November 7-10, 2010).

Munyaneza, J.E. 2010. Psyllids as vectors of emerging bacterial diseases of annual crops. Southwestern Entomologist 35: 417-477. 
Munyaneza, J.E., J.M. Crosslin, and J.E. Upton. 2006. The beet leafhopper (Hemiptera: Cicadellidae) transmits the Columbia Basin potato purple top phytoplasma to potatoes, beets, and weeds. Journal of Economic Entomology 99: 268-272.

Munyaneza, J.E., J.M. Crosslin, and J.E. Upton. 2007a. Association of Bactericera cockerelli (Homoptera: Psyllidae) with "zebra chip", a new potato disease in southwestern United States and Mexico. Journal of Economic Entomology 100: 656-663.

Munyaneza, J.E., J.A. Goolsby, J.M. Crosslin, and J.E. Upton. 2007b. Further evidence that zebra chip potato disease in the lower Rio Grande Valley of Texas is associated with Bactericera cockerelli. Subtropical Plant Science 59: 30-37.

Munyaneza, J.E., J.L. Buchman, J.E. Upton, J.A. Goolsby, J.M. Crosslin, G. Bester, G.P. Miles, and V.G. Sengoda. 2008. Impact of different potato psyllid populations on zebra chip disease incidence, severity, and potato yield. Subtropical Plant Science 60: 27-37.

Munyaneza, J.E., J.L. Buchman, and J.M. Crosslin. 2009a. Seasonal occurrence and abundance of the potato psyllid, Bactericera cockerelli, in south central Washington. American Journal for Potato Research 86: 513-518.

Munyaneza, J.E., V.G. Sengoda, J.M. Crosslin, G. De la Rosa-Lozano, and A. Sanchez. 2009b. First report of 'Candidatus Liberibacter psyllaurous' in potato tubers with zebra chip disease in Mexico. Plant Disease 93: 552.

Munyaneza, J.E., V.G. Sengoda, J.M. Crosslin, J. Garzon-Tiznado, and O. Cardenas-Valenzuela. 2009c. First report of 'Candidatus Liberibacter solanacearum' in tomato plants in Mexico. Plant Disease 93: 1076.

Munyaneza, J.E., J.L. Buchman, J.A. Goolsby, A.P. Ochoa, and G. Schuster. 2010a. Impact of potato planting timing on zebra chip incidence in Texas, pp. 106-109. In Proceedings of the 10th Annual Zebra Chip Reporting Session, ed. F. Workneh and C.M. Rush. Dallas, TX (November 7-10, 2010).

Munyaneza, J.E., J.L. Buchman, V.G. Sengoda, T.W. Fisher, G. Bester, R. Hoopes, C. Miller, R.G. Novy, P. Van Hest, and J. Nordgaard. 2010b. Potato variety screening trial for zebra chip resistance under controlled field cage conditions, pp. 200-203. In Proceedings of the 10th Annual Zebra Chip Reporting Session, ed. F. Workneh and C.M. Rush. Dallas, TX (November 7-10, 2010).

Munyaneza, J.E., T.W. Fisher, V.G. Sengoda, S.F. Garczynski, A. Nissinen, and A. Lemmetty. 2010c. First report of "Candidatus Liberibacter solanacearum" in carrots in Europe. Plant Disease 94: 639.

Munyaneza, J.E., T.W. Fisher, V.G. Sengoda, S.F. Garczynski, A. Nissinen, and A. Lemmetty. 2010d. Association of "Candidatus Liberibacter solanacearum" with the psyllid Trioza apicalis (Hemiptera: Triozidae) in Europe. Journal of Economic Entomology 103: $1060-1070$.

Munyaneza, J.E., J.L Buchman, B.E. Heilman, V.G. Sengoda, G. Bester, R. Hoopes, C. Miller, R. Novy, and P. Van Hest. 2011a. Update on potato variety screening trial for zebra chip under controlled field cage conditions, pp. 106-109. In Proceedings of the 11th Annual Zebra Chip Reporting Session, ed. F. Workneh, A. Rashed, and C.M. Rush. Dallas, TX (November 6-9, 2011).

Munyaneza, J.E., J.L. Buchman, B.E. Heilman, V.G. Sengoda, and D.C. Henne. 2011b. Effects of zebra chip and potato psyllid on potato seed quality, pp. 37-40. In Proceedings of the 11th Annual Zebra Chip Reporting Session, ed. F. Workneh, A Rashed, and C.M. Rush. Dallas, TX (November 6-9, 2011).

Munyaneza, J.E., A. Lemmetty, A.I. Nissinen, V.G. Sengoda, and T.W. Fisher. 2011c. Molecular detection of aster yellows phytoplasma and "Candidatus Liberibacter solanacearum" in carrots affected by the psyllid Trioza apicalis (Hemiptera: Triozidae) in Finland. Journal of Plant Pathology 93: 697-700.

Munyaneza, J.E., J.L. Buchman, V.G. Sengoda, T.W. Fisher, and C.C. Pearson. 2011d. Susceptibility of selected potato varieties to zebra chip potato disease. American Journal of Potato Research 88: 435-440.

Munyaneza, J.E., V.G. Sengoda, J.L. Buchman, and T.W. Fisher. 2012a. Effects of temperature on 'Candidatus Liberibacter solanacearum' and zebra chip potato disease symptom development. Plant Disease 96: 18-23.

Munyaneza, J.E., V.G. Sengoda, R. Stegmark, A.K. Arvidsson, O. Anderbrant, J.K. Yuvaraj, B. Ramert, and A. Nissinen. 2012b. First report of "Candidatus Liberibacter solanacearum" associated with psyllid-affected carrots in Sweden. Plant Disease 96: 453.

Munyaneza, J.E., V.G. Sengoda, L. Sundheim, and R. Meadow. 2012c. First report of "Candidatus Liberibacter solanacearum" associated with psyllid-affected carrots in Norway. Plant Disease 96: 454.

Nachappa, P., J. Levy, E. Pierson, and C. Tamborindeguy. 2011. Diversity of endosymbionts in the potato psyllid, Bactericera cockerelli (Hemiptera: Triozidae), vector of zebra chip disease of potato. Current Microbiology 62: 1510-1520.

Nachappa, P., A.A. Shapiro, and C. Tamborindeguy. 2012. Effect of 'Candidatus Liberibacter solanacearum' on fitness of its insect vector, Bactericera cockerelli (Hemiptera: Triozidae), on tomato. Phytopathology 102: 41-46.

Nansen, C., K. Vaughn, Y. Xue, C.M. Rush, F. Workneh, J.A. Goolsby, N. Troclair, J. Anciso, and X. Martini. 2010. Spray coverage and insecticide performance, pp. 78-82. In Proceedings of the 10th Annual Zebra Chip reporting Session, ed. F. Workneh and C.M. Rush. Dallas, TX (November 7-10, 2010).

Navarre, D.A., R. Shakya, J. Holden, and J.M. Crosslin. 2009. LC-MS analysis of phenolic compounds in tubers showing zebra chip symptoms. American Journal of Potato Research 86: 88-95.

Nelson, W.R., T.W. Fisher, and J.E. Munyaneza. 2011. Haplotypes of "Candidatus Liberibacter solanacearum" suggest long-standing separation. European Journal of Plant Pathology 130: 5-12.

Nicaragua-MAGFOR. 2012. Establecer medidas fitossanitarias para o manajo entegrado de "Punta Morada" e se vector Psilido Paratrioza nos cultivos de dolanaceas. OMC Mediante Notification Numero G/ SPS/N/NIC/65, 02 Marzo de 2012.

Nissinen, A.I., A. Lemmetty, J.M. Pihlava, L. Jauhiainen, J.E. Munyaneza, and P. Vanhala. 2012. Effects of carrot psyllid (Trioza apicalis) feeding on carrot yield and content of sugars and phenolic compounds. Annals of Applied Biology 161: 68-80.

Nolte, P., N. Olsen, E. Wenninger, and M. Thornton. 2011. Zebra chip found in Idaho, pp. 6. In Proceedings of the 11th Annual Zebra Chip Reporting Session, ed. F. Workneh, A. Rashed, and C.M. Rush. San Antonio, TX (November 6-9, 2011).

Novy, R.G., J. Whitworth, J. Alvarez, J.T. Trumble, C.D. Butler, J.L. Buchman, and J.E. Munyaneza. 2010. Unique tri-species germplasm with multiple insect resistances and its use in breeding for resistance to psyllid/ZC, pp. 103-105. In Proceedings of the 10th Annual Zebra Chip Reporting Session, ed. F. Workneh and C.M. Rush. Dallas, TX (November 7-10, 2010).

Ogden, S.C. 2011. Tomato potato psyllid and liberibacter in New Zealand - impact and research programme overview, pp. 173-177. In Proceedings of the 11th Annual Zebra Chip Reporting Session, ed. F. Workneh, A. Rashed, and C.M. Rush. San Antonio, TX (November 6-9, 2011).

Pearson, C.C., E.A. Backus, and J.E. Munyaneza. 2010. Feeding biology of the potato psyllid, Bactericera cockerelli, pp. 178-182. In Proceedings of the 10th Annual Zebra Chip Reporting Session, ed. F. Workneh and C.M. Rush. Dallas, TX (November 7-10, 2010).

Peng, L., J.T. Trumble, J.E. Munyaneza, and T.X. Liu. 2011. Repellency of a kaolin particle film to potato psyllid, Bactericera cockerelli (Hemiptera: Psyllidae), on tomato under laboratory and field conditions. Pest Management Science 67: 815-824.

Pierson, E., C. Miller, D. Scheuring, T.X. Liu, X. Yang, J. Jifon, D. Gross, R. Aravind, and J. Levy. 2010. Investigations on putative zebra chip (ZC) tolerant advanced selections, pp. 99-102. In 
Proceedings of the 10th Annual Zebra Chip Reporting Session, ed. F. Workneh and C.M. Rush. Dallas, TX (November 7-10, 2010).

Pitman, A.R., G.M. Drayton, S.J. Kraberger, R.A. Genet, and I.A.W. Scott. 2011. Tuber transmission of 'Candidatus Liberibacter solanacearum' and its association with zebra chip on potato in New Zealand. European Journal of Plant Pathology 129: 389-398.

Pletsch, D.J. 1947. The potato psyllid Paratrioza cockerelli (Sulc) its biology and control. Montana Agricultural Experiment Station Bulletin 446.

Price, D.R.G., and J.A. Gatehouse. 2008. RNAi-mediated crop protection against insects. Trends in Biotechnology 26: 393-400.

Puketapu, A., and N. Roskruge. 2011. The tomato-potato psyllid lifecycle on three traditional Maori food sources. Agronomy New Zealand 41: $167-173$.

Rashed, A., F. Workneh, L. Paetzold, J. Gray, C. Wallis, and C.M. Rush. 2011. Zebra chip disease severity and 'Candidatus Liberibacter solanacearum' titer load of the potato hosts inoculated throughout the field season, pp. 27-31. In Proceedings of the 11th Annual Zebra Chip Reporting Session, ed. F. Workneh, A. Rashed, and C.M. Rush. San Antonio, TX (November 6-9, 2011).

Ravindran, A., J. Levy, E. Pierson, and D. Gross. 2011a. Development of primers for improved PCR detection of the potato zebra chip pathogen, 'Candidatus Liberibacter solanacearum'. Plant Disease 95: $1542-1546$.

Ravindran, A., J. Levy, E. Pierson, D. Gross. 2011b. LAMP PCR lights the way for a simple, fast method for detection of Lso in infected potatoes and psyllids, pp. 79-82. In Proceedings of the 11th Annual Zebra Chip Reporting Session, ed. F. Workneh, A. Rashed, and C.M. Rush. San Antonio, TX (November 6-9, 2011).

Rehman, M., J. Melgar, C. Rivera, N. Urbina, A.M. Idris, and J.K. Brown. 2010. First report of "Candidatus Liberibacter psyllaurous" or "Ca. Liberibacter solanacearum" associated with severe foliar chlorosis, curling, and necrosis and tuber discoloration of potato plants in Honduras. Plant Disease 94: 376.

Richards, B.L. 1928. A new and destructive disease of the potato in Utah and its relation to the potato psylla. Phytopathology 18: 140-141.

Richards, B.L. 1931. Further studies with psyllid yellows of the potato. Phytopathology 21: 103.

Richards, B.L. 1933. Psyllid yellows of the potato. Journal of Agricultural Research 46: 189-216.

Richards, B.L., and H.L. Blood. 1933. Psyllid yellows of the potato. Journal of Agricultural Research 46: 189-216.

Romney, V.E. 1939. Breeding areas of the tomato psyllid, Paratrioza cockerelli (Sulc). Journal of Economic Entomology 32: 150-151.

Rondon, S., A. Schreiber, A. Jensen, P. Hamm, J.E. Munyaneza, P. Nolte, N. Olsen, E. Wenninger, D. Henne, C, Wohleb, and T. Waters. 2012. Potato psyllid vector of zebra chip disease in the Pacific Northwest: biology, ecology, and management. Oregon State University Extension Bulletin 633, online: http://ir.library. oregonstate.edu/xmlui/bitstream/handle/1957/30058/pnw633.pdf

Rosson, P. 2009. Economic impacts of zebra chip on Texas. CNAS Issue Brief 2009-01, AgriLife Research, Texas A \& M University.

Rowe, J.A., and G.F. Knowlton. 1935. Studies upon the morphology of Paratrioza cockerelli (Sulc). Journal of Utah Academic Science 12: 233-237.

Rubio-Covarrubias, O.A., I.H. Almeyda-Leon, J.I. Moreno, J.A. Sanchez-Salas, R.F. Sosa, J.T. Borbon-Soto, C.D. Hernandez, J.A. Garzon-Tiznado, R.R. Rodriguez, and M.A. CadenaHinajosa. 2006. Distribution of potato purple top and Bactericera cockerelli Sulc. in the main potato production zones in Mexico. Agricultura Técnica en México 32: 201-211.

Rubio-Covarrubias, O.A., I.H. Almeyda-Leon, M.A. Cadena-Hinajosa, and R. Lobato-Sanchez. 2011a. Relation between Bactericera cockerelli and presence of Candidatus Liberibacter psyllaurous in commercial fields of potato. Revista Mexicana de Ciencias Agricolas 2: 17-28.
Rubio-Covarrubias, O.A., M.A. Cadena-Hinajosa, and I.H. AlmeydaLeon. 2011b. A summary of research work on potato zebra chip in the central parts of Mexico, pp. 183-187. In Proceedings of the 11th Annual Zebra Chip Reporting Session, ed. F. Workneh, A. Rashed, and C.M. Rush. San Antonio, TX (November 6-9, 2011).

Rush, C.M., D.C. Henne, F. Workneh, and L. Paetzold. 2010. Investigating titer variation of Candidatus Liberibacter solanacearum in individual potato psyllids, pp. 19-23. In Proceedings of the 10th Annual Zebra Chip Reporting Session, ed. F. Workneh and C.M. Rush. Dallas, TX (November 7-10, 2010).

Schreiber, A., A. Jensen, and S. Rondon. 2012. Biology and management of potato psyllid in Pacific Northwest potatoes. Washington State Potato Commission Online: http://www.potatoes.com/IPMStuff/ PDFs/PotatoPsyllid.pdf

Scott, I., N. Berry, G. Walker, A. Pitman, P. Workman, and P. Wright. 2009. Psyllid, Liberibacter, and Phytoplasma Science Research Programme Update. Horticulture New Zealand, Plant and Food Research.Online: http://potatonz.org/user_files/PDF/Psyllid research_update_\&_control_options_-_Plant_\&_Food.pdf

Secor, G.A., and V. Rivera-Varas. 2004. Emerging diseases of cultivated potato and their impact on Latin America. Revista Latinoamericana de la Papa (Suplemento) 1: 1-8.

Secor, G.A., V. Rivera-Varas, J.A. Abad, I.M. Lee, G.R.G. Clover, L.W. Liefting, X. Li, and S.H. De Boer. 2009. Association of 'Candidatus Liberibacter solanacearum' with zebra chip disease of potato established by graft and psyllid transmission, electron microscopy, and PCR. Plant Disease 93: 574-583.

Sengoda, V.G., J.E. Munyaneza, J.M. Crosslin, J.L. Buchman, and H.R. Pappu. 2010. Phenotypic and etiological differences between psyllid yellows and zebra chip diseases of potato. American Journal of Potato Research 87: 41-49.

Šulc, K. 1909. Trioza cockerelli n. sp., a novelty from North America, being also of economic importance. Acta Societatis Entomologicae Bohemiae 6: 102-108.

Swisher, K.D., J.E. Munyaneza, and J.M. Crosslin. 2012. High resolution melting analysis of the cytochrome oxidase I gene identifies three haplotypes of the potato psyllid in the United States. Environmental Entomology 41: 1019-1028.

Teulon, D.A.J., P.J. Workman, K.L. Thomas, and M.C. Nielsen. 2009. Bactericera cockerelli: incursion, dispersal and current distribution on vegetable crops in New Zealand. New Zealand Plant Protection 62: 136-144.

Thomas, K.L., D.C. Jones, L.B. Kumarasinghe, J.E. Richmond, G.S.C. Gill, and M.S. Bullians. 2011. Investigation into the entry pathway for the tomato potato psyllid Bactericera cockerelli. New Zealand Plant Protection 64: 259-268.

Trevino, J., G. Schuster, S.D. Nelso, A.P. Ochoa, and J.E. Munyaneza. 2011. Effects of potato planting dates on psyllid populations and zebra chip incidence in Texas, pp. 127-130. In Proceedings of the 11th Annual Zebra Chip Reporting Session, ed. F. Workneh, A. Rashed, and C.M. Rush. Dallas, TX (November 6-9, 2011).

Trumble, J. 2008. The tomato psyllid: a new problem on fresh market tomatoes in California and Baja Mexico. University of California Cooperative Extension, http://ceventura.ucdavis.edu/Vegetable Crops/Tomato_Psyllid.htm.

Trumble, J. 2009. Potato psyllid. Center for Invasive Species Research, University of California Riverside, http://cisr.ucr.edu/potato_ psyllid.html.

Tucuch-Haas, J.I., J.C. Rodriguez-Maciel, A. Lagunes-Tejeda, G. Silva-Aguayo, S. Aguilar-Medel, A. Robles-bermudez, and J.M. Gonzalez-Camacho. 2010. Toxicity of spiromesifen to the development stages of Bactericera cockerelli (Sulc) (Hemiptera: Triozidae). Neotropical Entomology 39: 436-440.

Vega-Guttierrez, M.T., J.C. Rodriguez-Maciel, O. Diaz-Gomez, R. Bujanos-Muniz, D. Mota-Sanchez, J.L. Martinez-Carillo, A. Lagunes-Tejeda, and J.A. Garzon-Tiznado. 2008. Susceptibility 
to insecticides in two Mexican populations of tomato-potato psyllid, Bactericera cockerelli (Sulc) (Hemiptera: Triozidae). Agrociencia 42: 463-471.

Wallis, R.L. 1946. Seasonal occurrence of the potato psyllid in the North Platte Valley. Journal of Economic Entomology 39: 689694.

Wallis, R.L. 1955. Ecological studies on the potato psyllid as a pest of potatoes. USDA Technical Bulletin 1107.

Wallis, C.M., and J. Chen. 2011. Zebra chip symptoms are associated with increased phenolic, pathogenesis-related protein, and amino acid levels, pp. 159-162. In Proceedings of the 11th Annual Zebra Chip Reporting Session, ed. F. Workneh, A. Rashed, and C.M. Rush. San Antonio, TX (November 6-9, 2011).

Wen, A., I. Mallik, V.Y. Alvarado, J.S. Pasche, X. Wang, W. Li, L. Levy, H. Lin, H.B. Scholthof, T.E. Mirkov, C.R. Rush, and N.C. Gudmestad. 2009. Detection, distribution, and genetic variability of 'Candidatus Liberibacter' species associated with zebra complex disease of potato in North America. Plant Disease 93: 1102-1115.

Wen, A., H. Lin, and N.C. Gudmestad. 2011. Development of PCR assay using SSR primers for detection and genotyping of "Candidatus Liberibacter solanacearum", pp. 74-78. In Proceedings of the 11th Annual Zebra Chip Reporting Session, ed. F. Workneh, A. Rashed, and C.M. Rush. San Antonio, TX (November 6-9, 2011).

Workneh, F., J.A. Goolsby, D.C. Henne, A. Rashed, L. Paetzold, P.B. Hamm, S. Rondon, and C.M. Rush. 2011. Exploratory assessment of weather variables in relation to psyllid/ZC prevalence, pp. 7
11. In Proceedings of the 11th Annual Zebra Chip Reporting Session, ed. F. Workneh, A. Rashed, and C.M. Rush. San Antonio, TX (November 6-9, 2011).

Workneh, F., D.C. Henne, A.C. Childers, L. Paetzold, and C.M. Rush. 2012. Assessments of the edge effects in intensity of potato zebra chip disease. Plant Disease 96: 943-947.

Wuriyanghan, H., C. Rosa, and B.W. Falk. 2011. Oral delivery of double-stranded RNAs and siRNAs induces RNAi effects in the potato/tomato psyllid, Bactericera cockerelli. PloS One 6(11): e277736. doi:10.1371/journal.pone.0027736.

Yang, X.B., and T.X. Liu. 2009. Life history and life tables of Bactericera cockerelli (Homoptera: Psyllidae) on eggplant and bell pepper. Environmental Entomology 38: 1661-1667.

Yang, X.B., Y.M. Zhang, L. Hua, and T.X. Liu. 2010a. Life history and life tables of Bactericera cockerelli (Hemiptera: Psyllidae) on potato under laboratory and field conditions in the Lower Rio Grande Valley of Texas. Journal of Economic Entomology 103: 1729-1734.

Yang, X.B., Y.M. Zhang, L. Hua, L.N. Peng, J.E. Munyaneza, and T.X. Liu. 2010b. Repellency of selected biorational insecticides to potato psyllid, Bactericera cockerelli (Hemiptera: Psyllidae). Crop Protection 29: 1329-1324.

Zens, B., C.M. Rush, D.C. Henne, F. Workneh, E. Bynum, C. Nansen, and N.C. Gudmestad. 2010. Efficacy of seven chemical programs to control potato psyllids in the Texas Panhandle, pp. 83-87. In Proceedings of the 10th Annual Zebra Chip reporting Session, ed. F. Workneh and C.M. Rush. Dallas, TX (November 7-10, 2010). 